\title{
International Olympic Committee consensus statement on pain management in elite athletes
}

\author{
Brian Hainline, ${ }^{1}$ Wayne Derman, ${ }^{2}$ Alan Vernec, ${ }^{3}$ Richard Budgett, ${ }^{4}$ Masataka Deie, ${ }^{5}$ \\ Jiří Dvořák, ${ }^{6}$ Chris Harle, ${ }^{7}$ Stanley A Herring, ${ }^{8}$ Mike McNamee, ${ }^{9}$ Willem Meeuwisse, ${ }^{10}$ \\ G Lorimer Moseley, ${ }_{1}^{11}$ Bade Omololu, ${ }^{12}$ John Orchard, ${ }^{13}$ Andrew Pipe, ${ }^{14}$ \\ Babette M Pluim, ${ }^{15}$ Johan Ræder, ${ }^{16}$ Christian Siebert, ${ }^{17}$ Mike Stewart, ${ }^{18}$ Mark Stuart, ${ }^{19}$ \\ Judith A Turner, ${ }^{20}$ Mark Ware, $^{21}$ David Zideman, ${ }^{22}$ Lars Engebretsen ${ }^{4}$
}

\begin{abstract}
- Additional material is published online only. To view please visit the journal online (http://dx.doi.org/10.1136/ bjsports-2017-097884).

For numbered affiliations see end of article.
\end{abstract}

\section{Correspondence to}

Dr Brian Hainline, National Collegiate Athletic Association (NCAA), Indianapolis, Indiana 46206, US; bhainline@ncaa.org

Received 5 April 2017 Revised 10 June 2017 Accepted 26 June 2017 Published Online First 13 July 2017
CrossMark

$$
\begin{aligned}
& \text { To cite: Hainline B, } \\
& \text { Derman W, Vernec } A \text {, } \\
& \text { et al. } B r J \text { Sports Med }
\end{aligned}
$$$$
\text { 2017:51:1245-1258. }
$$

\section{ABSTRACT}

Pain is a common problem among elite athletes and is frequently associated with sport injury. Both pain and injury interfere with the performance of elite athletes. There are currently no evidence-based or consensusbased guidelines for the management of pain in elite athletes. Typically, pain management consists of the provision of analgesics, rest and physical therapy. More appropriately, a treatment strategy should address all contributors to pain including underlying pathophysiology, biomechanical abnormalities and psychosocial issues, and should employ therapies providing optimal benefit and minimal harm. To advance the development of a more standardised, evidenceinformed approach to pain management in elite athletes, an IOC Consensus Group critically evaluated the current state of the science and practice of pain management in sport and prepared recommendations for a more unified approach to this important topic.

\section{BACKGROUND}

The IOC convened a consensus meeting from 2 to 5 November 2016, at which experts reviewed the scientific literature addressing pain management in elite athletes. We searched for and analysed current best evidence, with the aim of reaching a consensus regarding the quality of the evidence in order to provide guidance for clinical practice and athlete management.

The group was charged with the following

- to review the literature describing pharmacological and non-pharmacological treatments for the management of pain in elite athletes

- to review the literature on the physiology of pain related to sport injury

- to establish core ethical and clinical principles for the management of pain in elite athletes

- to provide a sound rationale for the bestpractice management of pain in elite athletes

- to provide a rationale for the prohibition of certain analgesics and the basis for appropriately granting Therapeutic Use Exemptions for their use

- to provide a review of the risks and benefits of the use of analgesic medications in sport including short-term strategies to permit competition with optimal pain management.
This consensus paper fulfils the IOC charge by addressing the multifaceted aspects of pain physiology and pain management in elite athletes through the lenses of epidemiology, sports medicine, pain medicine, pain psychology, pharmacology and ethics.

\section{PREVALENCE OF USE OF PHARMACOLOGICAL AND NON-PHARMACOLOGICAL TREATMENTS TO MANAGE PAIN IN ELITE ATHLETES}

Elite athletes commonly use prescription and overthe-counter analgesics to prevent or relieve pain. ${ }^{1-18}$ These have typically included: oral non-steroidal anti-inflammatory drugs (NSAIDs), ${ }^{24616} 17$ injectable NSAIDs, ${ }^{5}$ other non-opioid analgesics, ${ }^{1} 489$ opioid analgesics, ${ }^{134781018}$ injectable and transdermal anaesthetics ${ }^{11}$ and other medications and over-the-counter supplements. ${ }^{13}{ }^{12-15}$

Despite the perception that the use of medications and non-pharmacological strategies to relieve and prevent pain is widespread in sport, ${ }^{89}{ }^{12}$ we could identify no comprehensive assessment of the frequency and effects of such use among elite athletes. Accordingly, a systematic literature review focusing on elite athletes' use of medications for pain was completed. The results are presented in detail in a separate article (Harle CA, Danielson EC, Smith L, et al. Analgesic management of pain in elite athletes: A systematic review. 2017, personal communication). A survey completed by team physicians during the 2016 Summer Olympics in Rio de Janeiro provides insight into physician prescribing patterns and is attached in supplementary online appendix A.

\section{TYPES OF PAIN}

'Pain management' includes a general understanding of pain physiology, including types of pain. By understanding types of pain, the clinician can better recommend an appropriate treatment plan. For a detailed discussion of core principles of pain physiology and pain management, the reader is referred to an accompanying article on this subject.

Pain is an unpleasant sensory and emotional experience associated with actual or potential tissue damage, or described in terms of such damage. ${ }^{19}$ (See supplementary online appendix B for definitions of key terminology.) Pain can be classified as nociceptive, neuropathic or nociplastic/algopathic/nocipathic. ${ }^{19-22}$ Nociceptive pain refers to 
pain clearly associated with tissue damage or inflammation. ${ }^{19} 20$ This is the type of pain most commonly associated with sport injury. ${ }^{19} 22$ Inflammatory pain is a type of nociceptive pain that results from the activation and sensitisation of nociceptors by inflammatory mediators ${ }^{20}$ and is common in acute traumatic sport injury with associated swelling and inflammation. ${ }^{20}$ Neuropathic pain results from a lesion or disease in the somatosensory nervous system ${ }^{19}$ and is common in Paralympic athletes with spinal cord injury. ${ }^{23} \mathrm{~A}$ third type of pain is common among individuals with chronic pain. These individuals have chronic pain that is neither nociceptive nor neuropathic but associated with clinical and psychophysical findings (hypersensitivity) that suggest altered nociceptive functioning (eg, as in fibromyalgia, non-specific low back pain). Terms proposed for this third type of pain include nociplastic, algopathic and nocipathic. ${ }^{22}$ Studies in athlete populations are lacking, but it is plausible that pain in the immediate aftermath of most sport injuries is nociceptive associated with tissue damage, and nociplastic/algopathic/nocipathic pain may develop after injury and may be seen in athletes with chronic pain.

\section{MECHANISMS AND TYPES OF INJURY}

The IOC has defined sports injury as new or recurring musculoskeletal complaints incurred during competition or training that require medical attention, regardless of the potential absence from competition or training. ${ }^{24}$ Others have suggested that a definition of sports injury should require restricted activity for at least 1 day. $^{25}$ (See appendix B for definitions of key terminology.)

Acute traumatic injury refers to a single event that leads to a singular macrotrauma on previously healthy tissue. ${ }^{26}$ Acute traumatic injury in the athlete may be accompanied by fear, anxiety and heightened cognitive focus on the injury. ${ }^{27}$

Overuse injuries occur from repetitive submaximal loading of the musculoskeletal system when inadequate recovery has not allowed structural adaptation to occur. ${ }^{28} 29$ Injury, then, is the outcome of the difference between the volume and intensity of the stress or force applied to the body and the body's ability to dissipate this stress or force. Injury may result from repetitive microtrauma imposed on otherwise healthy tissue or repeated application of lesser forces to already damaged tissue. In essence, athletes are not training at an optimal workload to build physical capacity and resilience to the demands of the sport. ${ }^{3031}$

Subacute recurrent injuries and chronic degenerative conditions may form a continuum with overuse injuries. A recurrent injury is an incident of the same type and at the same site linked to an index incident, which occurs after an athlete's return to full function and participation from the recorded index incident. ${ }^{32}$ Although degenerative conditions may develop independent of sport injury, some result from prior acute or repetitive overuse injuries and manifest as a chronic overuse injury. ${ }^{33}$

\section{CORE PRINCIPLES OF MAKING A DIAGNOSIS IN ELITE ATHLETES IN PAIN}

Sports medicine commonly focuses on the diagnosis and management of sport-related injury. Pain medicine focuses on the diagnosis and management of pain disorders. Importantly, injury may occur without pain, and pain may present without evidence of injury. When performing a history and examination of an elite athlete in pain, the sports medicine clinician should discern if there is an injury that reasonably accounts for pain. Pain management and injury management are not necessarily identical, as discussed in detail in this paper. Supplementary online appendix C provides an overview of core principles of diagnosis in elite athletes in pain.

\section{NON-PHARMACOLOGICAL PAIN MANAGEMENT STRATEGIES IN ELITE ATHLETES}

Non-pharmacological pain management should be considered in the earliest stages of pain and is essential in pain management beyond the acute phase. Pain is a subjective experience dependent on complex interactions of neurobiological, cognitive, affective, contextual and environmental factors. Thus, pain management depends on identifying contributory factors from biological, psychosocial and contextual domains and addressing them through various evidence-based techniques. ${ }^{34-36}$ Educating the athlete regarding the role of the central nervous system in pain, especially in chronic pain, can increase receptivity of the athlete to a biopsychosocial approach to pain management. ${ }^{34}$

Physical therapy is important for most pain problems, especially in subacute and chronic phases. ${ }^{37-39}$ In addition to therapy targeted at increasing strength, stamina, and endurance, and at correcting biomechanical contributors to pain and injury, trained and informed physical therapists can act as front-line clinicians who identify and address inaccurate conceptualisations of pain and injury plus psychosocial and contextual influences on pain. ${ }^{40-43}$ Psychological strategies, which can begin immediately after injury, also target pain management directly through training in skills such as muscle relaxation and imagery, as well as indirectly by identifying and addressing an athlete's worries and concerns, any comorbid mental health disorders and environmental factors relevant to recovery and return to play (RTP). ${ }^{44}$

\section{Modalities and massage}

Various modalities and massage have traditionally been the mainstays of physical therapy for pain. ${ }^{37-3946-49}$ The Rio Survey indicated that over $75 \%$ of physicians surveyed used physical therapy for pain management (appendix A). Recent studies, however, show that many physical therapy techniques have no clear benefit beyond non-specific effects and natural history, with some exceptions. Low-level laser therapy may be beneficial in treating tendinopathy and improving acute muscle recovery. ${ }^{50-54}$ Although cryotherapy is commonly used, there is little evidence from prospective studies assessing the benefit of this intervention. ${ }^{54-56}$ Ultrasound therapy may have a limited role in managing plantar fasciitis ${ }^{56}$ but has not demonstrated effectiveness in other studies. ${ }^{57}$ Electrical stimulation, ${ }^{49}$ 58-60 massage therapy, ${ }^{48}$ 61-63 myofascial trigger point treatments ${ }^{64-67}$ and acupuncture ${ }^{68-70}$ have not shown reliable and consistent efficacy for relief of pain resulting from musculoskeletal injury.

The effects of modalities may be manifest in an individually specific way, especially as it pertains to the skill of the treating clinician. ${ }^{61-75}$ That is, the patient's and the clinician's expectations and skill, respectively, about a particular treatment's mechanism and effects are potentially powerful determinants of outcome. ${ }^{76-78}$ The practitioner needs to balance the relative weight of expectation of benefit (and therefore likely benefit) with potential risk.

\section{Movement, strength and conditioning}

Movement and exercise may have pain-relieving effects. ${ }^{79} 80$ Strength training and conditioning are effective as rehabilitation tools after injury. They can also be helpful in managing pain and reversing deconditioning in individuals with chronic painful conditions such as osteoarthritis, ${ }^{81-84}$ fibromyalgia ${ }^{85-92}$ and chronic musculoskeletal pain. ${ }^{93}$ Exercise can activate 
endogenous opioid ${ }^{95}$ and cannabinoid systems, ${ }^{96}$ induce an anti-inflammatory state ${ }^{97}$ and activate antinociceptive pathways. $^{95}$ 98-101 Isometric exercise can promote intracortical inhibition (which downregulates brain networks that subserve pain) and may offer significant pain-relieving benefits beyond those offered by isotonic and eccentric exercises for managing tendinopathy. ${ }^{102-104}$ Although data from athletes are lacking, there is evidence in other pain populations (particularly chronic pain) that movement and exercise-based approaches can improve patient self-efficacy for managing pain and fear of (re)injury. ${ }^{34} 44$

\section{Psychosocial interventions}

Psychosocial interventions with possible efficacy in sports rehabilitation include skills training in goal setting, imagery, relaxation and positive self-statements. ${ }^{105}$ Stress inoculation training was shown to reduce anxiety, pain and days to recovery after arthroscopic surgery for meniscus injury. ${ }^{106}$ Other interventions relevant to athletes include cognitive restructuring (identifying and challenging negatively biased appraisals) and developing plans for maintaining treatment gains and coping with setbacks and pain flare-ups. ${ }^{105}$ These strategies are broadly categorised as cognitive-behavioural therapies (CBTs). CBT is the prevailing psychosocial treatment for chronic pain problems, and there is high-level evidence of its efficacy in reducing pain and pain-related disability in studies of non-athletes. ${ }^{105} 107108$ Psychologically informed physical therapy, which incorporates cognitive and behavioural principles and strategies (eg, techniques to reduce fear-avoidance, use of graded activity and exposure techniques), and education about pain during physical rehabilitation, is a promising approach with some evidence supporting its use. ${ }^{34} 109$ Psychological assessment and intervention by a specialist should be normalised by the treatment and coaching team, so that it can be implemented when necessary and without stigma.

\section{Sleep and nutrition}

Disordered sleep is common among athletes, both when recovering from injury and during the competition and training seasons. ${ }^{110111}$ Sleep and pain have a reciprocal relationship-pain disturbs sleep, and poor sleep quality or duration increases pain levels in clinical populations and decreases pain thresholds in otherwise healthy people. ${ }^{112-118}$ Addressing sleep disorders could improve performance and the general health of the athlete. ${ }^{111}$ Psychological strategies including CBT, ${ }^{119}$ self-hypnosis ${ }^{120}$ and mindfulness-based stress reduction ${ }^{121}$ show significant potential to improve sleep in non-athletes. CBT for insomnia has demonstrated efficacy. ${ }^{122-124}$ Studies in athlete populations are lacking, but it is plausible that these results would be generalisable to athletes.

Persistent pain is influenced by any proinflammatory load, ${ }^{125}$ which makes nutrition possibly relevant to managing pain in athletes. However, studies demonstrating benefit from nutritional supplements are not methodologically sound and have unclear relevance to elite athletes. ${ }^{126-138}$ Furthermore, supplements are poorly regulated and may contain banned substances. Consequently, supplements cannot currently be recommended as part of pain management for elite athletes.

\section{Surgery}

Elective surgery has no place in the treatment of pain itself but may address structural damage non-responsive to non-operative treatment, or to avoid further impairment of an athlete's health. ${ }^{139}$ An operation for a chronic injury and pain condition must aim to correct a structural problem that influences pain and functional limitations ${ }^{140-142}$ and should occur as part of a multifaceted, biopsychosocial management approach. ${ }^{143}$ Surgical intervention includes setting individual treatment and outcome goals for the athlete. The athlete must have a complete understanding of the risks and benefits and accurate expectations about postsurgical recovery and pain. When appropriate, surgery can be part of a multidisciplinary approach for pain reduction. Surgery should not be performed to treat chronic pain simply because all other interventions have failed but should rather be used when a structural problem associated with the pain has been identified. ${ }^{139}$

\section{PHARMACOLOGICAL PAIN MANAGEMENT STRATEGIES IN ELITE ATHLETES \\ Guiding principles}

Appropriate and effective pain management requires a thoughtful and individualised approach to evaluation and care, including an assessment of the implications of treatment for both short-term and long-term health. ${ }^{144}$ The prescription, or provision, of medication is common to the management of pain in elite athletes. Analgesic medications should be used in accordance with relevant regulations and the general guidelines for their safe and efficacious use. ${ }^{145}$ The core pharmacological principles of pain management in elite athletes include:

- Medication prescription should be only one component of managing pain. Combining medication use with appropriate non-pharmacological measures limits disability and optimises probability of improvement.

- Medications should be prescribed at the lowest effective dose for the shortest period of time. They should be discontinued if they are ineffective or not tolerated, and as the pain from the injury resolves.

- Medications should be prescribed in a manner consistent with established, recognised pharmacological and pharmacodynamic principles, including route of administration, time of onset of action, effectiveness for pain relief and potential side effects and complications. Consideration of an athlete's medical and medication history is essential.

- Physicians prescribing analgesic medications to athletes should possess a complete understanding of the prevailing rules and regulations regarding prohibited substances and Therapeutic Use Exemptions specific to the governing body that controls the athlete's sport.

- Recording athlete-reported severity of pain (eg, with a numerical rating scale) can be useful in monitoring the effectiveness of a medication.

- Prescription medications should only be provided to athletes by licenced healthcare providers who understand potential side effects or misuse of medications, and whose licensure includes this scope of practice. Written documentation of each assessment and prescription is a basic standard of care.

- Informed consent is fundamental in medical care, including those situations in which medication is prescribed. This is also true for care of the elite athlete; however, obtaining such consent can be challenging in competitive situations when an athlete seeks same-day RTP. At a minimum, any substantial risk of short-term or long-term worsening of an injury should be discussed and documented.

- Medications should not be prescribed to athletes for pain or injury prevention. 


\begin{tabular}{ll}
\hline $\begin{array}{l}\text { Table } 1 \text { Medications for managing acute, severe pain from a severe } \\
\text { injury that does }\end{array}$ & not allow same-day return to play \\
\hline Intravenous & Morphine $(10 \mathrm{mg})$ \\
Inhalation & Fentanyl $(100 \mathrm{mcg}$, titrated to effect) \\
& Entonox/Nitronox (inhaled $50: 50$ oxygen and nitrous oxide \\
& mixture) \\
Intranasal & Methoxyflurane/penthrox \\
& Diamorphine (1600 $\mathrm{mcg}$ in commercially available \\
& administrator $)$
\end{tabular}

\section{MEDICATION MANAGEMENT BASED ON PAIN SEVERITY AND ANTICIPATED RTP}

I. Medications for managing acute pain in the elite athlete on the same day as the injury: on the field of play, sideline or locker room

Physicians providing care at a practice or game/match scenario should have a comprehensive emergency medical action plan, including provisions for acute pain management. ${ }^{146}$ Pain management may depend on whether same-day RTP is contemplated.

\section{No same-day RTP}

A major acute injury with associated severe pain may require pain management on the field of play or on the sidelines (table 1). Extending the hospital emergency department onto the field of play may be necessary. The severely injured athlete must receive effective pain treatment as soon as possible, and certainly before any prehospital treatment (eg, manipulation or splinting) is attempted. ${ }^{146}$

\section{Same-day RTP}

Medications may play a central role in the management of an athlete with acute pain who is considered for same-day RTP. Paracetamol, NSAIDs and local anaesthetics are commonly employed in such situations ${ }^{147-157}$ (table 2). Knowledge of

\begin{tabular}{|c|c|}
\hline \multicolumn{2}{|c|}{ Mild to moderate pain } \\
\hline Paracetamol (oral) & $\begin{array}{l}\text { Loading dose up to } 2 \mathrm{~g} \text {, then } 325-1000 \mathrm{mg} \text { PO every } \\
4-6 \text { hours, up to } 4 \mathrm{~g} \text { per } 24 \text { hours }\end{array}$ \\
\hline NSAIDs (oral) & $\begin{array}{l}\text { Ibuprofen: } 400-800 \mathrm{mg} \text { every } 4-6 \text { hours with food, up } \\
\text { to } 3200 \mathrm{mg} \text { per } 24 \text { hours } \\
\text { Naproxen: } 250-500 \mathrm{mg} 2 \times \text { daily with food } \\
\text { Ketorolac: } 10 \mathrm{mg} \text { every } 4-6 \text { hours with food, up to } \\
40 \mathrm{mg} \text { per } 24 \text { hours } \\
\text { Celecoxib: } 200-400 \mathrm{mg} 2 \times \text { daily } \\
\text { Etoricoxib: } 90-120 \mathrm{mg} \text { once daily }\end{array}$ \\
\hline Topical analgesics & $\begin{array}{l}\text { Rubefacients: methyl salicylate; turpentine oil; } \\
\text { ammonia water } \\
\text { Cooling sensation: camphor; menthol } \\
\text { Vasodilation: histamine dihydrochloride; methyl } \\
\text { nicotinate } \\
\text { Irritation without rebefaction: capsaicin; capsicum } \\
\text { oleoresin }\end{array}$ \\
\hline \multicolumn{2}{|c|}{ Moderate to severe pain } \\
\hline NSAIDs (injection) & $\begin{array}{l}\text { Ketorolac: } 15-30 \mathrm{mg} \text { IM or IV up to } 4 \times / \text { day, at least } \\
6 \text { hours apart, or a single } 60 \mathrm{mg} \text { injection }\end{array}$ \\
\hline $\begin{array}{l}\text { Local anaesthetic } \\
\text { injections }\end{array}$ & \\
\hline
\end{tabular}

IV, intravenous; NSAIDs, non-steroidal anti-inflammatory drugs; IM, intramuscular; PO, oral. relevant pharmacokinetics, including time to onset of action and plasma concentrations, is valuable. The primary determinant when providing analgesics in same-day RTP situations is the athlete's safety. ${ }^{145} 156$ Analgesia that allows competition should not place the athlete at risk of worsening injury.

For mild to moderate pain, paracetamol, alone or with NSAIDs, will usually suffice. ${ }^{152} 157$ Paracetamol does not have an effect on the gastric mucosa, renal function or platelet activityconsiderations that should figure prominently in prescribing analgesic medication to those participating in sport. ${ }^{158}$ NSAIDs may be slightly more analgesic than paracetamol ${ }^{159}$ and together provide more pain relief than either alone. ${ }^{157160}$ It is important that paracetamol be given in sufficient dosing, including a $2 \mathrm{~g}$ loading dose and $1 \mathrm{~g}$ every $4-6$ hours thereafter, as needed. ${ }^{161}$ Intramuscular ketorolac has been widely used in certain elite sports because of possible greater analgesic efficacy without significant reported side effects, ${ }^{5}$ although concerns remain ${ }^{162}$ and prescribing recommendations are narrow. ${ }^{5} 163$ If the injury develops with an ongoing haematoma, ketorolac and traditional NSAIDs may worsen the bleeding, whereas this is no concern with paracetamol or a COX-2 selective NSAID. ${ }^{164}$ Topical anaesthetics may provide relief of well-localised, more superficial conditions such as intercostal pain. ${ }^{156}$

For moderate to severe pain, paracetamol and NSAIDs remain an option, including paracetamol with ketorolac. Opioid use in an opioid-naïve individual is usually associated with cognitive, behavioural and reaction-time effects detrimental to individual performance ${ }^{165166}$ and may theoretically place other athletes at risk in sports that require quick reaction time in a crowded space (cycling and basketball). There is no compelling evidence demonstrating that opioids such as tramadol and codeine provide pain relief that is superior to NSAIDs. ${ }^{154}$ Tramadol can also impair reaction time in tramadol-naïve individuals. ${ }^{154}$ Thus, opioids have little or no role in same-day RTP; if anything, they are ergolytic, not ergogenic.

Injected local anaesthetics have also been used for moderate to severe pain and same-day RTP in elite athletes, either pregame or during competition. ${ }^{151} 153$ There are some limited data from a case series of National Rugby League players. ${ }^{153}$ Most governing bodies, including the World Anti-Doping Agency (WADA), have not banned these injections. ${ }^{167}$ Intra-articular injections of local anaesthetic should be avoided into weight-bearing joints or as intratendon or intraligament injections. ${ }^{151} 153$

Corticosteroid injections have no role for same-day RTP. They do not provide pain relief superior to that of local anaesthetics $^{168} 169$ and can cause acute muscle/tendon weakening, thereby increasing the chance of injury. ${ }^{168-171}$ Other injections, such as platelet-rich plasma (PRP) and intra-articular viscosupplementation, are not useful for same-day RTP. ${ }^{172-175}$

\section{Medications for managing mild to moderate acute pain in the} elite athlete beyond the day of injury

Medications should not be prescribed as a stand-alone treatment when managing acute pain beyond same-day RTP in athletes. ${ }^{144}$ It is essential to diagnose the injury and the cause of pain and to begin rehabilitation that addresses both. Thus, non-pharmacological strategies should begin immediately.

Medications for acute pain should normally not be used for more than 5 days. ${ }^{150176177}$ The Rio Survey (supplementary online appendix A) indicated that $31 \%$ of physicians usually prescribe NSAIDs for 1-2 days' duration, 42\% prescribe a 3-5 day course and $21 \%$ prescribe NSAIDs for longer than 7 days. Even for more severe injuries with associated moderate to severe pain, medications should be re-evaluated if pain persists beyond 10 days. The process should address the underlying injury or pathology 
Box 1 Medication management for acute pain (pain

duration less than 4-6 weeks) beyond the day of injury

Mild to moderate pain

Oral paracetamol, non-steroidal anti-inflammatory drugs,

topical analgesics, as per table 2 .

Corticosteroid injections (equivocal evidence):

- Intra-articular

- Bursal

- Peritendinous

- Epidural

- Facet

- Sacroiliac

Severe pain commensurate with injury Consider adding opioids:

- Initial prescription not to exceed 5 days

- No opioid prescription beyond 10 days

and the possibility that pain characteristics are changing (see below). ${ }^{150} 177$

The most appropriate medications for treating mild to moderate acute pain in the elite athlete beyond the day of injury include oral paracetamol and oral NSAIDs. ${ }^{150} 156157$ (box 1) Both provide good pain relief, but the risk-benefit profile is considerably different. Paracetamol is a non-specific analgesic without anti-inflammatory agents and usually lacks other systemic side-effects when used in prescription doses. Hepatotoxicity occurs in daily doses greater than 4 g. ${ }^{158}$

The choice of paracetamol versus NSAIDs ${ }^{147}$ may have more to do with physician preference in using one medication or another. NSAIDs may be slightly more analgesic than paracetamol, ${ }^{159}$ but together provide more pain relief than either alone. ${ }^{157} 160$ If there is no known inflammatory contributor to pain, paracetamol is preferable to an NSAID because of its lower risk profile in the majority of people. ${ }^{150}$

Corticosteroid injections must be coordinated carefully with other aspects of rehabilitation, since their suppression of the inflammatory cascade may hinder tissue healing. ${ }^{172} 173$ Their pain-relieving effects may result in worsening of the injury if the exercise programme exceeds the capacity of the injured tissue. ${ }^{172} 173$ Overall, the evidence suggests that corticosteroid injections may provide pain relief and hasten rehabilitation but do not improve tissue healing. ${ }^{178-189}$ The incidence of complications of corticosteroid injection in treating athletic injuries is unknown. ${ }^{168} 170171$

Two other types of injection therapies used are PRP therapy and viscosupplementation. PRP has been used to address a variety of conditions ranging from acute muscle injury to tendinopathy to osteoarthritis. The literature on the efficacy of PRP has been hampered by methodological limitations. Although some encouraging results have been reported, more large, methodologically rigorous randomised, double-blinded studies are needed before endorsing this treatment. ${ }^{174}{ }^{175}{ }^{190-197}$ Viscosupplementation has been most studied in the treatment of knee osteoarthritis. The highest quality randomised controlled studies show only mild pain relief and functional improvement compared with placebo injections. ${ }^{198} 199$

III. Use of medications for managing severe acute pain in the elite athlete beyond the day of injury
When an athlete has severe acute pain, relief of pain is not only humane but may be necessary to facilitate early mobilisation. ${ }^{200201}$ The Rio Survey indicated that $71 \%$ of the Olympic team physicians surveyed considered the ability to enable rehabilitation exercises to be an important factor when forming a treatment plan for an athlete (supplementary online appendix A). It is reasonable to begin treatment with paracetamol and/or NSAIDs, as indicated. ${ }^{147-150} 202203$ Injection medications may also be considered. ${ }^{172} 173$

In a dose-dependent manner, opioids are the most effective medications for severe acute pain. ${ }^{204-207}$ However, many risks are associated with opioid use. Thus, before prescribing opioids, the physician should ${ }^{208-213}$ :

- make a diagnosis that includes assessment of pain and its relationship to the injury, including whether the athlete's pain seems appropriate for the injury

- establish and measure goals for pain relief and improved function

- assess current status and personal history with respect to mental health and alcohol and other substance use, validate such history with other health professionals involved in the patient's care if necessary and incorporate strategies to mitigate risks of opioid use

- Begin first-line non-opioid therapy and evaluate adherence to and effectiveness of the treatment before considering initiation of opioid therapy unless pain is severe and clearly associated with an injury consistent with that level of pain

- prescribe the lowest effective dose and limit prescription of opioids to 5 days. Ongoing use can be reconsidered but should rarely exceed 10 days and should be accompanied by informed consent regarding the risks of opioid dependence or addiction as well as overdose, especially if used in combination with alcohol or benzodiazepines.

- opioid use beyond 10 days should be considered with caution. Opioid therapy is rarely appropriate for longer than 10 days after an acute painful injury. Risks increase substantially with the number of days opioids are used. Opioid use for more than 7 days after painful musculoskeletal work injury has been associated with increased odds of disability 1 year later. ${ }^{214}$ The likelihood of chronic opioid use increases with each additional day of medication supplied starting with the third day, with the sharpest increase in chronic opioid use observed after the 5 th day on therapy, a second prescription or refill and an initial 10-day or 30-day supply. ${ }^{215}$ If opioids are prescribed for more than 10 days, it is essential to have a plan in place for limiting risk of diversion and a plan and timeline for discontinuing opioid use.

\section{Medications for managing subacute and chronic pain in the} elite athlete

Pain associated with sport injury may be acute (up to 6 weeks) subacute (6-12 weeks) or chronic (3 months or longer). ${ }^{216}$ When pain has persisted beyond 6 weeks of an injury or inciting event, the influences on pain and disability should be re-explored. In most cases, there is no sound rationale for long-term use of NSAIDs for pain management in elite athletes. ${ }^{150} 176177$ Although paracetamol may be used intermittently, there is no strong rationale for using this class of medication beyond the acute period. ${ }^{150}$ Considerable caution should be used in considering the use of opioid medication to treat subacute or chronic pain, given the serious risks and lack of evidence regarding benefits associated with long-term use. ${ }^{208} 209$ Importantly, individuals whose pain has not responded to treatment and who develop subacute and chronic pain have a 
Table 3 Acute, subacute and chronic pain: definitions and treatment implications

\begin{tabular}{lll}
\hline Pain duration & Type of pain & Treatment considerations \\
\hline$<6$ weeks & Acute & $\begin{array}{l}\text { Treatment focused on treating injury and managing pain, including identifying possible psychosocial and environmental factors } \\
\text { influencing pain. }\end{array}$ \\
\hline $6-12$ weeks & $\begin{array}{l}\text { Subacute } \\
>12 \text { weeks }\end{array}$ & $\begin{array}{l}\text { Approach shifts from management of acute pain to improving function and preventing chronic pain and associated disability. } \\
\text { Identify and continue to address psychosocial/environmental factors influencing pain, disability and dysfunction. Focus should be } \\
\text { on improving function. }\end{array}$ \\
\hline
\end{tabular}

higher risk profile for addiction and comorbid psychiatric conditions. ${ }^{204} 207-212$

Perhaps the most important consideration in managing subacute and chronic pain in elite athletes is to shift the treatment approach from relieving pain to improving function and preventing chronic pain and associated disability (table 3). Treatment should involve a multidisciplinary approach. ${ }^{217-220}$ Analgesic medications used to treat acute pain in elite athletes should rarely be used for subacute and chronic pain. Athletes should be informed that analgesic medications carry risks, especially when used long term. ${ }^{221-224}$

Chronic pain may be associated with psychosocial factors, including mood and sleep disturbance, fear of pain and reinjury, avoidance of activities believed to increase pain or cause physical harm, concern about not achieving pre-injury level of proficiency and perception of being disconnected from coaches and teammates. ${ }^{40-45} 225$ It is especially important to address the common comorbid conditions of depression, anxiety and sleep disorder. ${ }^{221} 222$

Before beginning adjuvant medications for chronic pain, if possible the athlete should be evaluated by a clinician with experience in managing chronic pain. ${ }^{218}$ Consideration should be given to pain being driven by peripheral nociceptive activation versus neuropathic or nociplastic/algopathic/nocipathic pain. The most commonly used adjuvants for treating chronic, neuropathic or nociplastic/algopathic/nocipathic pain are anticonvulsants and antidepressants ${ }^{221} 226-231$ (table 4). Caution must be applied for treating adolescent elite athletes with adjuvant medications. For more localised pain, second-line medications include capsaicin patches (8\%) and lidocaine patches. Tramadol may have a role in some cases of chronic pain because of its dual mechanism of action as a weak opioid and an upregulator of the serotonin system, but more research is needed to increase knowledge of benefits and risks. ${ }^{228}$

\section{$V$. The special case of cannabinoids}

A cannabinoid is one of a class of diverse chemical compounds that activates the endogenous endocannabinoid system. ${ }^{232}$
Exogenous cannabinoids include phytocannabinoids such as tetrahydrocannabinol and cannabidiol, and synthetic cannabinoids such as K2 and 'spice'. Cannabis has been cited as possibly a useful substance for pain management. ${ }^{233-235}$ Indeed, it has been said in the popular press that cannabis is safer than opioids and should be used instead of opioids for managing chronic musculoskeletal pain in American football players. ${ }^{236}$ However, current evidence suggests that opioids should rarely be prescribed for chronic musculoskeletal pain, ${ }^{208-212}$ and evidence is lacking concerning the benefits and risks of cannabis for chronic musculoskeletal pain management. Cannabis has no role in the management of severe acute pain, as no studies have demonstrated its efficacy in this situation. ${ }^{237}$

Cannabinoids have been studied for treatment of pain conditions including neuropathic pain, fibromyalgia, spinal cord injury, spasticity from multiple sclerosis, HIV neuropathy and cancer pain. In general, the studies are short term and small and show minor or modest improvement in pain relief. ${ }^{238} 239$ There is good evidence that cannabinoids have a modest analgesic effect for some pain conditions such as, for example, refractory neuropathic pain. ${ }^{240}{ }^{241}$ Cannabinoids are considered possible third-line agents for some chronic pain conditions. ${ }^{242}$ Cannabinoids are considered ergolytic, ${ }^{242}$ and like opioids, carry risks, including addiction. In summary, current evidence does not justify the use of cannabinoids for pain management in elite athletes.

\section{PAIN MANAGEMENT STRATEGIES WHEN EXPECTED RECOVERY IS DELAYED}

It should be kept in mind that pain is a conscious experience that can be influenced by a variety of factors, including nociceptive activity and cognitive and affective factors. Pain is not necessarily related in a linear manner to nociceptive input. ${ }^{23}$ Optimal clinical management continually evaluates these various influences on pain independent of injury. Unique considerations for the elite athlete in pain relate to competitive requirements and demands

Table 4 Selected adjuvant medications for neuropathic and nociplastic/algopathic/nocipathic pain in adults*

\begin{tabular}{ll}
\hline First-line medications & Total daily dose and dose regimen \\
\hline Anticonvulsants & Begin at $100-300 \mathrm{mg} 1-3 \times /$ day; may be increased to $1200-3600 \mathrm{mg} /$ day in three divided doses \\
\hline Gabapentin & Begin at 25 to $75 \mathrm{mg} 1-2 \times /$ day; may be increased up to a dose of $150-600 \mathrm{mg} /$ day in divided doses \\
\hline $\begin{array}{l}\text { Pregabalin } \\
\text { Antidepressants }\end{array}$ & Begin at 20 to $30 \mathrm{mg} 1 \times /$ day; may be increased up to $120 \mathrm{mg} 1 \times /$ day \\
\hline $\begin{array}{l}\text { Serotonin-noradrenaline reuptake inhibitors: duloxetine } \\
\text { Serotonin-noradrenaline reuptake inhibitors: venlafaxine ER }\end{array}$ & Begin at $37.5-75 \mathrm{mg} 1 \times /$ day; may be increased to $225 \mathrm{mg} 1 \times /$ day or in divided doses \\
\hline Tricyclic: amitriptyline or nortriptyline & Begin at $10-20 \mathrm{mg}$ at night; may be increased to $150 \mathrm{mg}$ at night \\
\hline Second-line medications & Total daily dose and dose regimen \\
\hline Capsaicin $8 \%$ patches & $1-4$ patches to painful area for $30-60$ min $\mathrm{q} 3$ months \\
\hline Lidocaine patches & $1-3$ patches to painful region $1 \times /$ day for up to 12 hours and then off for 12 hours \\
\hline Tramadol & $50-400 \mathrm{mg} 2-3 \times /$ day \\
\hline${ }^{*}$ There are many elite athletes who are teenagers and young adults, and an expert in managing this population should be consulted before beginning anticonvulsants or \\
antidepressants for pain management.
\end{tabular}




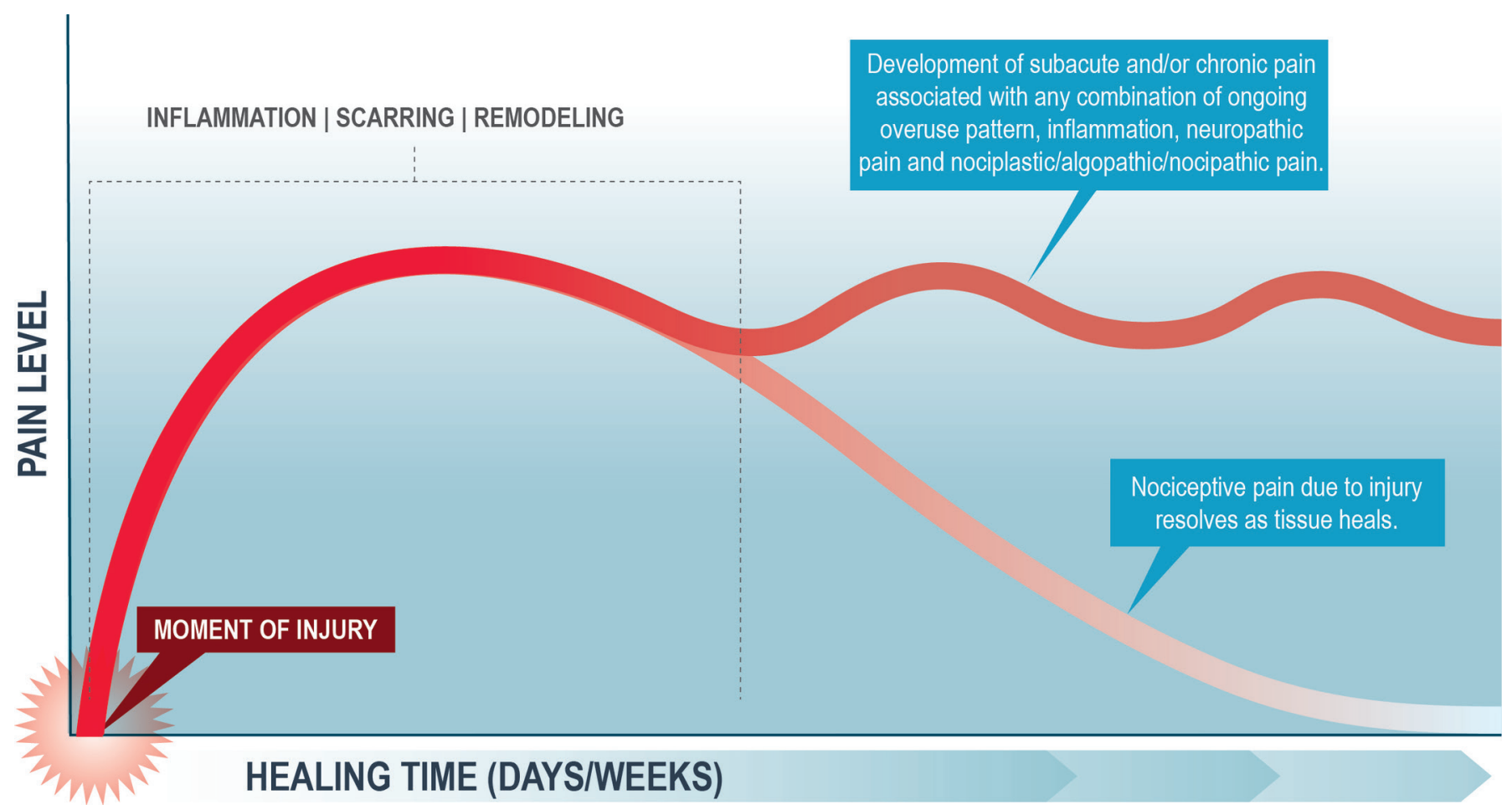

Figure 1 Pain variation following injury based on influences of pain. Adapted with permission, Butler DS and Moseley GL: Explain Pain, 2nd Edition, Noigroup Publications, 2013.

and relationships between the athlete and his/her professional and medical teams. The motivation of elite athletes to maximise bodily performance is another factor in pain assessment and has important implications for management in a clinically optimal and ethically appropriate manner. ${ }^{40-45} 225$

Pain management plans should be communicated openly with the athlete and all those involved in management of the athlete's injury, recovery and RTP. A plan for reassessment at critical time points should be established and clearly communicated to all parties, especially when athletes change their treating team during their recovery. This protocol should include the plan for injury and pain management and information about the predicted time course of pain, rehabilitation and key milestones. ${ }^{200}$

In the acute phase, emphasis should be on reassuring the athlete and providing education about realistic expectations, the normal course of the injury and associated pain (figure 1). ${ }^{27} 243$ The athlete should understand his/her role in optimising recovery. Accurate injury diagnosis underpins expectations about the path to recovery and pain resolution. Most athletes will recover from injury in the predicted manner. ${ }^{244}$ However, monitoring recovery closely, quickly identifying any deviation from the predicted path (figure 1) and re-assessing if recovery is not occurring as predicted are all of critical importance.

There is ample literature and clinical experience regarding anticipated recovery from many sport injuries. ${ }^{244-251}$ Box 2 provides a checklist that can be used clinically to evaluate need for further assessment. When pain fails to improve as expected, or changes in its distribution or quality, a prompt reevaluation is indicated, with three distinct but related objectives: (1) determination of whether the initial diagnosis is correct; (2) determination of whether the injury is healing as expected; and (3) identification of important non-injury factors that may be influencing the pain. Each objective may require assessment by a different clinician, further imaging or other testing. In most cases, the physical therapist (or other treating clinician such as athletic trainer) should be involved in monitoring recovery milestones, minimising impact of the injury and optimising return to performance. When the athlete's pain interferes with recovery in an atypical manner, the physical therapist and other treating clinicians must assess and respond to possible contributors, including biomechanics and the kinetic chain continuum, and psychosocial and contextual domains. ${ }^{23} 252253$

There are two clear triggers for involving psychological assessment and treatment: (1) the clinician may identify psychosocial issues likely contributing to poor recovery and requiring a specialist; or (2) pain and function have not improved as expected within a few weeks after injury. ${ }^{27} 246247250251$ A psychologist can assess modifiable psychosocial influences on pain, treatment adherence and pain-related performance issues, and work with the athlete to address these barriers to recovery. Key psychosocial factors associated with poor treatment adherence and outcomes after sport injury include mood

\section{Box 2 Checklist to assess need for further evaluation}

(Positive response indicates risk of deviation from the predicted path to recovery)

- Is the pain worsening, spreading or both?

- Is pain occurring at rest or during the night?

- Has any new pain emerged in other anatomical locations?

- Does the pain fluctuate in a manner not explained by mechanical load?

- Does the pain seem out of proportion to the severity of the injury?

- Is the quality of the pain changing or is the pain becoming more distressing?

- Has the athlete's expectations of recovery changed for the worse? 


\begin{tabular}{ll}
\hline Table $5 \quad 2017$ WADA Prohibited List \\
\hline Prohibited at all times \\
\hline Prohibited & S0: Non-approved substances \\
substances & S1: Anabolic agents \\
& S2: Peptide hormones, growth factors, related substance \\
& and mimetics \\
& S3: Beta-2 agonists \\
& S4: Hormone and metabolic modulators \\
& S5: Diuretics and masking agents \\
Prohibited methods & M1: Manipulation of blood and blood components \\
& M2: Chemical and physical manipulation \\
& M3: Gene doping \\
\hline
\end{tabular}

\begin{tabular}{ll}
\hline Prohibited in competition only \\
\hline $\begin{array}{l}\text { Prohibited } \\
\text { substances in all }\end{array}$ \\
sports & Narcotics \\
& Buprenorphine; dextromoramide; diamorphine (heroin); \\
& fentanyl and its derivatives; hydromorphone; methadone; \\
& morphine; nicomorphine; oxycodone; oxymorphone; \\
pentazocine; pethidine & Cannabinoids \\
& Glucocorticoids \\
Prohibited & Alcohol \\
substances in select & Beta-blockers \\
sports & \\
\hline WADA, World Anti-Doping Agency.
\end{tabular}

disturbance, fear of reinjury, concern about not achieving preinjury level of proficiency and feeling disconnected from coaches and teammates. ${ }^{19} 23252-255$ Other more general psychosocial influences include anxiety, stress, catastrophising (excessively negative appraisals of pain and its implications), depression and maladaptive fear of pain and re-injury and consequent avoidance of activities believed to increase pain, cause physical harm or both. ${ }^{2341} 43225253$ Finally, other mental health problems (eg, eating or substance use disorders) can also impede recovery and require a psychologist's intervention. The assessment must also evaluate the context and meaning of the prolonged pain and slow return to performance. $251256-258$

\section{ANTIDOPING ISSUES IN PAIN MANAGEMENT}

'Narcotic Analgesics' was a category of the initial IOC 'Prohibited' list. ${ }^{167}$ The 'Narcotics' section was retained in the 'Prohibited List' developed by the WADA, its IOC successor (see table 5). Cannabis was also added to the WADA Prohibited List. Despite public perception that analgesic use might allow athletes to enhance performance, there is scant evidence to support this hypothesis, as noted below.

Substances or categories may be added or subtracted to the Prohibited List annually, via a process that includes extensive stakeholder feedback and deliberation by experts, based on the latest scientific evidence available. A substance will be considered for inclusion in the Prohibited List if it meets two out of the three following criteria:

- Use of the substance would enhance or has the potential to enhance sport performance.

- Use of the substance poses an actual or potential health risk.

- Use of the substance would be seen as contrary to the 'spirit of sport'.

Therapeutic Use Exemptions (TUEs) allow the use of a prohibited substance to treat legitimate medical conditions or injury. ${ }^{259}$ The criteria for granting a TUE include the following:

- The absence of treatment would pose a significant detriment to the athlete's health.
- Treatment will produce no performance-enhancing effect, other than the return to the athlete's normal state of health.

- No reasonable permitted therapeutic alternative exists.

TUEs can also be provided retroactively, if the treatment was provided in an acute situation. Retroactive TUEs are also allowed under exceptional circumstances, such as insufficient opportunity to submit an application.

There is limited literature to suggest that any analgesics enhance performance. Small, unblinded studies typically involving non-elite subjects have suggested that paracetamol can improve time to exhaustion ${ }^{260}$ or decrease perceived exertion in a graded run. ${ }^{261262}$ NSAIDs have no effect on sprinting, ${ }^{263}$ vertical jumping or endurance running performance but can decrease soreness. ${ }^{2}{ }^{263-265}$ Opioids can decrease pain ${ }^{265}$ and increase anaerobic performance ${ }^{265}$ but not overall physical performance after muscle damage. ${ }^{265}$ Opioids can increase tolerance to pain associated with tourniquet-induced ischaemia, ${ }^{266}$ but the translation to elite athlete performance is unclear. Attenuated afferent feedback following opioid use may cause a greater rate of accumulation of muscle metabolites and excessive development of peripheral muscle fatigue. ${ }^{267}$ Cannabis can reduce anxiety, ${ }^{242} 268$ but no ergogenic effects have been demonstrated. ${ }^{242} 269$

Pain management decisions should be made carefully, respecting confidentiality issues and ensuring appropriate consent where appropriate. The use of analgesics should be guided by pain severity and anticipated RTP, as noted above, and by the core principles described in this consensus document. Items on the Prohibited List should be used sparingly to globally regulate this important area of professional practice and allow individualised yet responsible treatment.

\section{SPECIAL CONSIDERATIONS: PARALYMPIC ATHLETES}

Para-athletes can experience more pain than their able-bodied counterparts, perhaps because of an increased incidence of injuries in their sports, or the nature of a specific impairment. ${ }^{270} 271$ Although pain or discomfort in para-athletes can be a common clinical feature among those within each of the 10 recognised impairment categories, more severe pain can occur in those experiencing stump pain, phantom limb pain, spasticity-related pain or in those who have suffered spinal cord injuries. ${ }^{272}$

Central neuropathic pain is common in athletes following a spinal cord injury or stroke or in those with multiple sclerosis. ${ }^{273}$ One study estimated the incidence of neuropathic pain following a spinal cord injury to be 53\% for neuropathic pain at the level of the lesion, and 27\% for neuropathic pain below the level of the lesion. ${ }^{274}$ Phantom limb pain can affect up to $80 \%$ of lower limb amputees, and pain in the stump residuum can occur in $55 \%-76 \%$ of these individuals. ${ }^{275}$ Chronic musculoskeletal pain is estimated to occur in $60 \%-80 \%$ of individuals with cerebral palsy and reflects increased muscle tone, dystonia and spasticity. ${ }^{276} 277$ The use of pain medications, particularly those used to treat chronic neuropathic pain, is therefore higher in para-athletes than in their able-bodied counterparts. ${ }^{278} 279$

\section{ETHICAL ISSUES}

Understanding how pain is experienced by an athlete is important. ${ }^{280}$ Part of the socialisation of athletes in male sport includes a degree of (hyper)masculinisation, leading to efforts to disregard or downplay pain and injury. ${ }^{281}$ Similar norms may exist in women's and girls' sports. ${ }^{282}$ More recently, the literature has addressed the phenomenology (felt experience) of pain ${ }^{283}$; pain may be an everyday experience for elite athletes, and an 
abrupt change in pain experience may indicate a clinically relevant change in biomechanical, psychological or social factors. ${ }^{284}$

Managing pain in elite athletes must account for the tension between ignoring or masking pain versus understanding the protective role of pain in the presence of injury. The IOC medical code is clear in this regard and asserts that 'The health and the welfare of athletes are pre-eminent and prevail over competitive, economic, legal or political considerations'. ${ }^{285}$ This principle emphasises the primacy and protects the integrity of the clinical encounter, which is pre-eminent in ensuring appropriate pain management. Pain and injury mechanisms can be complex; the clinician must have appropriate time and space to diagnose and delineate treatment options.

The principle of respect for patient autonomy is codified in procedures for informed consent. ${ }^{286}$ These processes seek to assure the patient's comprehension and his/her voluntary decision making. It is not always clear when an athlete makes an informed choice to 'play through pain' and when he/she may be under duress from stakeholders within their sports environment. ${ }^{287-289}$ The principle of non-maleficence (do no harm) must guide the clinician's actions and recommendations to the patient in acute pain. In chronic pain contexts, however, there are broader opportunities for discussions with the patient, including an evaluation of short-term and long-term goals, the potential for emotional conflicts that may arise with prolonged suffering and the possibility of more pronounced external influences on ethical decision making. ${ }^{280} 290$ Therefore, an informed and well-documented discussion should occur between the clinician, the broader healthcare team and the athlete when considering approaches to the management of chronic pain. ${ }^{291}$

\section{FUTURE DIRECTIONS}

Pain management in the elite athlete should always follow principles of good medicine, be multidisciplinary and occur with the understanding that pain and injury are not the same. Further research and increased consistency in measures and methods across studies are needed to better understand the incidence and prevalence of analgesic medication use in sport, and the benefits and risks of various pharmacological and non-pharmacological treatments, and their combinations, for specific pain presentations. There is an urgent need to increase awareness of sports medicine physicians of recent advances in the understanding of pain and its management through evidence-based guidance, as well as for increased research on pain and its management in elite athletes, in order to improve treatment of this important problem. Given that pain is commonly self-managed by athletes using over-the-counter pain medications or supplements, information specifically aimed at athletes on the safe and efficacious use of pain medications is also warranted.

\footnotetext{
Author affiliations

${ }^{1}$ National Collegiate Athletic Association (NCAA), Indianapolis, Indiana, USA

${ }^{2}$ Stellenbosch University, Stellenbosch, South Africa

${ }^{3}$ World Anti-Doping Agency, Montreal, Canada

${ }^{4}$ International Olympic Committee, Lausanne, Switzerland

${ }^{5}$ Aichi Medical University, Nagakute, Japan

${ }^{6}$ Department of Neurology, Schulthess Clinic Zurich, Zürich, Switzerland

${ }^{7}$ Department of Health Policy and Management, Indiana University, Indianapolis,

Indiana, USA

${ }^{8}$ University of Washington, Seattle, Washington, USA

${ }^{9}$ Swansea University, Swansea, UK

${ }^{10}$ University of Calgary, Calgary, Canada

${ }^{11}$ University of South Australia, Adelaide, South Australia

${ }^{12}$ University of Ibadan College of Medicine, Ibadan, Nigeria

${ }^{13}$ Cricket Australia, Melbourne, Australia

${ }^{14}$ University of Ottawa Heart Institute, Ottawa, Canada
}

${ }^{15}$ Chief Medical Adviser, Koninklijke Nederlandse Lawn Tennis Bond (KNLTB),

Amersfoort, The Netherlands

${ }^{16}$ Oslo University, Oslo, Norway

${ }^{17}$ Hanover Medical School, Hanover, Germany

${ }^{18}$ East Kent Hospitals University NHS Foundation Trust, Canterbury, Great Britain

${ }^{19}$ Mark Stuart, Bpharm FFRPS FRPharmS, BJM, London, UK

${ }^{20}$ University of Washington, Seattle, Washington, USA

${ }^{21}$ MBBS MRCP, McGill University Health Centre, Montreal, Canada

${ }^{22}$ International Olympic Committee Medical and Scientific Games Group, Lausanne Switzerland

Disclaimer This consensus paper provides an overview of pain management issues in elite athletes that are important to physicians and other clinicians who treat elite athletes. It is not intended as a clinical practice guideline or legal standard of care and should not be interpreted as such. This consensus paper serves as a guide and, as such, is of a general nature, consistent with the reasonable practice of the healthcare professional. Individual treatment will depend on the facts and circumstances specific to each individual case.

Competing interests None declared.

Provenance and peer review Not commissioned; externally peer reviewed.

(C) Article author(s) (or their employer(s) unless otherwise stated in the text of the article) 2017. All rights reserved. No commercial use is permitted unless otherwise expressly granted.

\section{REFERENCES}

1 Huang SH, Johnson K, Pipe AL. The use of dietary supplements and medications by Canadian athletes at the Atlanta and Sydney Olympic Games. Clin I Sport Med 2006;16:27-33

2 Da Silva ER, De Rose EH, Ribeiro JP, et al. Non-steroidal anti-inflammatory use in the XV Pan-American Games (2007). Br J Sports Med 2011;45:91-4.

3 Tscholl $P$, Junge A, Dvorak J. The use of medication and nutritional supplements during FIFA World Cups 2002 and 2006. Br J Sports Med 2008;42:725-30.

4 Derman EW, Schwellnus MP. Pain management in sports medicine: Use and abuse of anti-inflammatory and other agents. South African Family Practice 2010;52:27-32.

5 Sawyer GA, Anderson BC, Raukar NP, et al. Intramuscular ketorolac injections in the athlete. Sports Health 2012;4:319-27.

6 Warden SJ. Prophylactic use of NSAIDs by Athletes: a risk/benefit assessment. Phys Sportsmed 2010;38:132-8.

7 Corrigan B, Kazlauskas R. Medication Use in Athletes selected for doping control at the Sydney Olympics (2000). Clinical Journal of Sport Medicine 2003;13:33-40.

8 Alaranta A, Alaranta $H$, Heliövaara M, et al. Ample use of physician-prescribed medications in finnish elite Athletes. Int J Sports Med 2006;27:919-25.

9 Suzic Lazic J, Dikic N, Radivojevic N, et al. Dietary supplements and medications in elite sport - polypharmacy or real need? Scand J Med Sci Sports 2011;21:260-7.

10 Thuyne WV, Delbeke FT. Declared use of medication in sports. Clin I Sport Med 2008; 18:143-7

11 Tscholl P, Alonso JM, Dollé G, et al. The use of drugs and nutritional supplements in top-level track and field athletes. Am J Sports Med 2010;38:133-40.

12 Outram SM, Stewart B. Condemning and condoning: Elite amateur cyclists' perspectives on drug use and professional cycling. Int I Drug Policy 2015:26:682-7.

13 Tricker R. Painkilling drugs in collegiate athletics: knowledge, attitudes, and use of student athletes. J Drug Educ 2000;30:313-24.

14 Taioli E. Use of permitted drugs in Italian professional soccer players. Br J Sports Med 2007;41:439-41

15 Küster M, Renner B, Oppel $\mathrm{P}$, et al. Consumption of analgesics before a marathon and the incidence of cardiovascular, gastrointestinal and renal problems: a cohort study. BMJ Open 2013;3:e002090.

16 Warner DC, Schnepf G, Barrett MS, et al. Prevalence, attitudes, and behaviors related to the use of nonsteroidal anti-inflammatory drugs (NSAIDs) in student athletes. J Adolesc Health 2002;30:150-3.

17 Paoloni JA, Milne C, Orchard J, et al. Non-steroidal anti-inflammatory drugs in sports medicine: guidelines for practical but sensible use. Br J Sports Med 2009;43:863-5.

18 Tsitsimpikou C, Tsiokanos A, Tsarouhas K, et al. Medication use by athletes at the Athens 2004 Summer Olympic Games. Clin J Sport Med 2009:19:33-8.

19 Hainline B, Turner J, Caneiro J, et al. Pain in elite athletes: neurophysiological, biomechanical and psychosocial considerations. Br J Sports Med 2017;51:1259-64.

20 Loeser JD, Treede RD. The Kyoto protocol of IASP basic pain terminology. Pain 2008:137:473-7.

21 Vardeh D, Mannion RJ, Woolf CJ. Toward a Mechanism-Based approach to pain diagnosis. J Pain 2016;17(9 Suppl):T50-T69.

22 Jensen TS, Baron R, Haanpää M, et al. A new definition of neuropathic pain. Pain 2011:152:2204-5.

23 Kosek E, Cohen M, Baron R, et al. Do we need a third mechanistic descriptor for chronic pain states? Pain 2016;157:1382-6. 
24 Tracey I, Mantyh PW. The cerebral signature for pain perception and its modulation. Neuron 2007:55:377-91.

25 Engebretsen L, Soligard T, Steffen $\mathrm{K}$, et al. Sports injuries and illnesses during the London Summer Olympic Games 2012. Br J Sports Med 2013;47:407-14.

26 Swenson DM, Yard EE, Fields SK, et al. Patterns of recurrent injuries among US high school Athletes, 2005-2008. Am J Sports Med 2009;37:1586-93.

27 Steindler A. Kinesiology of the human body: under normal and pathological conditions. Springfield, IL: Charles C Thomas Pub Ltd, 1955.

28 Prien A, Mountjoy M, Miller J, et al. Injury and illness in aquatic sport: how high is the risk? A comparison of results from three FINA World Championships. Br J Sports Med 2017;51.

29 DiFiori JP, Benjamin HJ, Brenner J, et al. Overuse injuries and burnout in youth sports: a position statement from the American Medical Society for Sports Medicine. Clin J Sport Med 2014;24:3-20.

30 Paterno MV, Taylor-Haas JA, Myer GD, et al. Prevention of overuse sports injuries in the young athlete. Orthop Clin North Am 2013;44:553-64.

31 Gabbett TJ. The training-injury prevention paradox: should athletes be training smarter and harder? Br J Sports Med 2016;50:273-80.

32 Hulin BT, Gabbett TJ, Lawson DW, et al. The acute:chronic workload ratio predicts injury: high chronic workload may decrease injury risk in elite rugby league players. Br J Sports Med 2016;50:231-6.

33 Fagher K, Jacobsson J, Timpka T, et al. The Sports-Related Injuries and IIInesses in Paralympic Sport Study (SRIIPSS): a study protocol for a prospective longitudinal study. BMC Sports Sci Med Rehabil 2016:8:28-37.

34 Yang J, Tibbetts AS, Covassin T, et al. Epidemiology of overuse and acute injuries among competitive collegiate athletes. J Athl Train 2012;47:198-204.

35 Moseley GL, Butler DS. Fifteen years of explaining pain: The Past, present, and future. J Pain 2015;16:807-13.

36 Moseley GL, Vlaeyen JW. Beyond nociception: the imprecision hypothesis of chronic pain. Pain 2015;156:35-8.

37 Wallwork SB, Bellan V, Catley MJ, et al. Neural representations and the cortical body matrix: implications for sports medicine and future directions. Br J Sports Med 2016:50:990-6.

38 Grant ME, Steffen K, Glasgow $\mathrm{P}$, et al. The role of sports physiotherapy at the London 2012 Olympic Games. Br J Sports Med 2014;48:63-70.

39 Rajan P, Bellare B. Referring doctors' perspectives about Physiotherapy management for chronic musculoskeletal pain. International Journal of Therapies and Rehabilitation Research 2013;2:15-21.

40 Spetch LA, Kolt GS. Adherence to sport injury rehabilitation: implications for sports medicine providers and researchers. Physical Therapy in Sport 2001;2:80-90.

41 Ardern CL, Webster KE, Taylor NF, et al. Return to sport following anterior cruciate ligament reconstruction surgery: a systematic review and meta-analysis of the state of play. Br J Sports Med 2011:45:596-606.

42 Czuppon S, Racette BA, Klein SE, et al. Variables associated with return to sport following anterior cruciate ligament reconstruction: a systematic review. Br J Sports Med 2014:48:356-64.

43 Lentz TA, Zeppieri G, George SZ, et al. Comparison of physical impairment, functional, and psychosocial measures based on fear of reinjury/lack of confidence and return-to-sport status after ACL reconstruction. Am J Sports Med 2015:43:345-53.

44 te Wierike SC, van der Sluis A, van den Akker-Scheek I, et al. Psychosocial factors influencing the recovery of athletes with anterior cruciate ligament injury: a systematic review. Scand J Med Sci Sports 2013;23:527-40.

45 Forsdyke D, Smith A, Jones M, et al. Psychosocial factors associated with outcomes of sports injury rehabilitation in competitive athletes: a mixed studies systematic review. Br J Sports Med 2016;50:537-44.

46 Podlog L, Heil J, Schulte S. Psychosocial factors in sports injury rehabilitation and return to play. Phys Med Rehabil Clin N Am 2014;25:915-30.

47 Denegar CR SE, Saliba S. Therapeutic modalities for musculoskeletal injuries. 4 ed: Human Kinetics Publishers, 2015.

48 Knight KKK, Draper DO. Therapeutic modalities: the Art and Science: lippincott Williams \& Williams, 2012.

49 Best TM, Hunter R, Wilcox A, et al. Effectiveness of sports massage for recovery of skeletal muscle from strenuous exercise. Clin J Sport Med 2008;18:446-60.

50 Elboim-Gabyzon M, Rozen N, Laufer Y. Does neuromuscular electrical stimulation enhance the effectiveness of an exercise programme in subjects with knee osteoarthritis? A randomized controlled trial. Clin Rehabil 2013;27:246-57.

51 Leal-Junior EC. Photobiomodulation therapy in skeletal muscle: from exercise performance to muscular dystrophies. Photomed Laser Surg 2015;33:53-4.

52 Bjordal JM, Johnson MI, Iversen $\mathrm{V}$, et al. Low-level laser therapy in acute pain: a systematic review of possible mechanisms of action and clinical effects in randomized placebo-controlled trials. Photomed Laser Surg 2006;24:158-68.

53 Nogueira AC, Júnior MJ. The effects of laser treatment in tendinopathy: a systematic review. Acta Ortop Bras 2015;23:47-9.

54 Tumilty S, Mani R, Baxter GD. Photobiomodulation and eccentric exercise for Achilles tendinopathy: a randomized controlled trial. Lasers Med Sci 2016;31:127-35.

55 De Marchi T, Machado GP SVM , et al. Does photobiomodulation therapy work better than cryotherapy in muscle recovery after a high-intensity exercise?
A randomized, double-blind, placebo-controlled clinical trial. Lasers Med Sci 2017:34:429-37.

56 Malanga GA, Yan N, Stark J. Mechanisms and efficacy of heat and cold therapies for musculoskeletal injury. Postgrad Med 2015;127:57-65.

57 Yu H, Randhawa K, Côté P, et al. The effectiveness of physical agents for Lower-Limb Soft tissue injuries: a systematic review. J Orthop Sports Phys Ther 2016;46:523-54.

58 Desmeules F, Boudreault J, Roy JS, et al. The efficacy of therapeutic ultrasound for rotator cuff tendinopathy: A systematic review and meta-analysis. Phys Ther Sport 2015;16:276-84

59 Feger MA, Herb CC, Fraser JJ, et al. Supervised rehabilitation versus home exercise in the treatment of acute ankle sprains: a systematic review. Clin Sports Med 2015:34:329-46.

60 Feger MA, Goetschius J, Love $\mathrm{H}$, et al. Electrical stimulation as a treatment intervention to improve function, edema or pain following acute lateral ankle sprains: a systematic review. Phys Ther Sport 2015;16:361-9.

61 Sisk TD, Stralka SW, Deering MB, et al. Effect of electrical stimulation on quadriceps strength after reconstructive surgery of the anterior cruciate ligament. Am J Sports Med 1987; 15:215-20

62 Brummitt J. The role of massage in sports performance and rehabilitation: current evidence and future direction. N Am J Sports Phys Ther 2008;3:7.

63 Poppendieck WWM, Ferrauti A, et al. Massage and performance recovery and injury prevention. Sports Medicine 2016;46:183-204.

64 Weerapong P, Hume PA, Kolt GS. The mechanisms of massage and effects on performance, muscle recovery and injury prevention. Sports Med 2005;35:235-56.

65 Quintner JL, Bove GM, Cohen ML. A critical evaluation of the trigger point phenomenon. Rheumatology 2015;54:392-9.

66 Mauntel TC, Clark MA, Padua DA. Effectiveness of Myofascial Release Therapies on Physical Performance Measurements: A Systematic Review. Athletic Training \& Sports Health Care 2014;6:189-96.

67 Meakins A. Soft tissue sore spots of an unknown origin. Br J Sports Med 2015;49:348.

68 Dommerholt J, Bron C, Franssen J. Myofascial trigger Points: an evidence-informed review. Journal of Manual \& Manipulative Therapy 2006;14:203-21.

69 Cox J, Varatharajan S, Côté P, et al. Are Acupuncture Therapies Effective for the management of musculoskeletal disorders fo the Extremeties? A systematic review by the Ontario Protocol for Traffic INjury Management (Optima) Collaboration. The Journal of Orthopaedic and Sports Physical Therapy 2016;46:409-29.

70 Barlas P, Robinson J, Allen J, et al. Lack of effect of acupuncture upon signs and symptoms of delayed onset muscle soreness. Clin Physiol 2000;20:449-56.

71 Kleinhenz J, Streitberger K, Windeler J, et al. Randomised clinical trial comparing the effects of acupuncture and a newly designed placebo needle in rotator cuff tendinitis. Pain 1999:83:235-41.

72 Tejero-Fernández V, Membrilla-Mesa M, Galiano-Castillo N, et al. Immunological effects of massage after exercise: A systematic review. Phys Ther Sport 2015;16:187-92.

73 Gerwin RD, Dommerholt J, Shah JP. An expansion of Simons' integrated hypothesis of trigger point formation. Curr Pain Headache Rep 2004;8:468-75.

74 Simons DG, Travell JG, Simons LS, et al. Travell \& Simons' Myofascial Pain and Dysfunction: The Trigger Point Manual. Volume 1. Philadelphia, PA: Lippincott Williams \& Wilkins 1999

75 Mora-Relucio R, Núñez-Nagy S, Gallego-Izquierdo T, et al. Experienced versus Inexperienced Interexaminer Reliability on Location and Classification of Myofascial Trigger Point Palpation to Diagnose Lateral Epicondylalgia: An Observational CrossSectional Study. Evid Based Complement Alternat Med 2016:2016:1-8.

76 Cambron JA, Dexheimer J, Coe P. Changes in blood pressure after various forms of therapeutic massage: a preliminary study. J Altern Complement Med 2006; 12:65-70

77 Stone DA, Kerr CE, Jacobson E, et al. Patient expectations in placebo-controlled randomized clinical trials. J Eval Clin Pract 2005;11:77-84.

78 Turner JA, Jensen MP, Warms CA, et al. Blinding effectiveness and association of pretreatment expectations with pain improvement in a double-blind randomized controlled trial. Pain 2002;99:91-9.

79 Semino $\mathrm{E}$. The adaptation of metaphors across genres. Review of Cognitive Linguistics 2011;9:130-52.

80 Sluka KA, Skyba DA, Radhakrishnan R, et al. Joint mobilization reduces hyperalgesia associated with chronic muscle and joint inflammation in rats. J Pain 2006;7:602-7.

81 Moss P, Sluka K, Wright A. The initial effects of knee joint mobilization on osteoarthritic hyperalgesia. Man Ther 2007;12:109-18.

82 Bennell K, Hinman R. Exercise as a treatment for osteoarthritis. Curr Opin Rheumato 2005; 17:634-40

83 Jansen MJ, Viechtbauer W, Lenssen AF, et al. Strength training alone, exercise therapy alone, and exercise therapy with passive manual mobilisation each reduce pain and disability in people with knee osteoarthritis: a systematic review. J Physiother 2011:57:11-20.

84 Burrows NJ, Booth J, Sturnieks DL, et al. Acute resistance exercise and pressure pain sensitivity in knee osteoarthritis: a randomised crossover trial. Osteoarthritis Cartilage 2014;22:407-14. 
85 Tanaka R, Ozawa J, Kito N, et al. Efficacy of strengthening or aerobic exercise on pain relief in people with knee osteoarthritis: a systematic review and meta-analysis of randomized controlled trials. Clin Rehabil 2013;27:1059-71.

86 Gusi N, Tomas-Carus P, Häkkinen A, et al. Exercise in waist-high warm water decreases pain and improves health-related quality of life and strength in the lower extremities in women with Fibromyalgia. Arthritis Rheum 2006;55:66-73.

87 Busch AJ, Schachter CL, Overend TJ, et al. Exercise for Fibromyalgia: a systematic review. J Rheumatol 2008:35:1130-44.

88 Kayo AH, Peccin MS, Sanches CM, et al. Effectiveness of physical activity in reducing pain in patients with Fibromyalgia: a blinded randomized clinical trial. Rheumatol Int 2012;32:2285-92.

89 Hooten WM, Qu W, Townsend CO, et al. Effects of strength vs aerobic exercise on pain severity in adults with Fibromyalgia: a randomized equivalence trial. Pain 2012;153:915-23.

$90 \mathrm{Jm}$ T. Exercise in muscle pain disorder. PM\&R: The journal of injury, function and rehabilitation 2012;4:889-93.

91 Busch A. Resistance exercise training for Fibromyalgia. The Cochrane Library: Cochrane Database of Systematic Reviews, 2012.

92 Larrson APA, Löfgren M, et al. Resistance exercise improves muscle strength, health status and pain intensity in Fibromyalgia: a randomized controlled trial. Arthritis Research \&Amp. Therapy 2015;17:161.

93 Nelson NL. Muscle strengthening activities and fibromyalgia: a review of pain and strength outcomes. J Bodyw Mov Ther 2015;19:370-6.

94 Ferrell $B A$, Josephson $\mathrm{KR}$, Pollan $\mathrm{AM}$, et al. A randomized trial of walking versus physical methods for chronic pain management. Aging 1997;9:99-105.

95 Falla $D$, Jull $G$, Hodges $P$, et al. An endurance-strength training regime is effective in reducing myoelectric manifestations of cervical flexor muscle fatigue in females with chronic neck pain. Clin Neurophysiol 2006:117:828-37.

96 Boecker H, Sprenger T, Spilker ME, et al. The runner's high: opioidergic mechanisms in the human brain. Cereb Cortex 2008:18:2523-31.

97 Fuss J, Steinle J, Bindila L, et al. A runner's high depends on cannabinoid receptors in mice. Proc Natl Acad Sci U S A 2015;112:13105-8.

98 Gleeson M, Bishop NC, Stensel DJ, et al. The anti-inflammatory effects of exercise: mechanisms and implications for the prevention and treatment of disease. Nat Rev Immunol 2011;11:607-15.

99 Pagano RL, Fonoff ET, Dale CS, et al. Motor cortex stimulation inhibits thalamic sensory neurons and enhances activity of PAG neurons: possible pathways for antinociception. Pain 2012;153:2359-69.

100 França NR, Toniolo EF, Franciosi AC, et al. Antinociception induced by motor cortex stimulation: somatotopy of behavioral response and profile of neuronal activation. Behav Brain Res 2013;250:211-21.

101 Fonoff ET, Dale CS, Pagano RL, et al. Antinociception induced by epidural motor cortex stimulation in naive conscious rats is mediated by the opioid system. Behav Brain Res 2009;196:63-70.

102 Rio E, Kidgell D, Purdam C, et al. Isometric exercise induces analgesia and reduces inhibition in patellar tendinopathy. Br J Sports Med 2015:49:1277-83.

103 Rio E, Kidgell D, Moseley GL, et al. Tendon neuroplastic training: changing the way we think about tendon rehabilitation: a narrative review. Br J Sports Med 2016;50:209-15.

104 Rio E, Moseley L, Purdam C, et al. The pain of tendinopathy: physiological or pathophysiological? Sports Med 2014;44:9-23.

105 Rio $E$, van Ark M, Docking S, et al. Isometric contractions Are more analgesic than isotonic contractions for patellar tendon pain: an in-season randomized clinical trial. Clin J Sport Med 2017:27:253-259.

106 De C Williams A, Eccleston C, Morley S. Psychological therapies for the management of chronic pain (excluding headache) in adults: The Cochrane Library, 2012.

107 Ross MJ, Berger RS. Effects of stress inoculation training on athletes' postsurgical pain and rehabilitation after orthopedic injury. J Consult Clin Psychol 1996:64:406-10.

108 Richmond H, Hall AM, Copsey B, et al. The effectiveness of cognitive behavioural treatment for non-specific low back pain: a Systematic review and meta-analysis. PLoS One 2015;10:e0134192.

109 Cherkin DC, Sherman KJ, Balderson BH, et al. Effect of mindfulness-based stress reduction vs cognitive behavioral therapy or usual care on back pain and functional limitations in adults with chronic low back Pain. JAMA 2016;315:1240-9.

110 Nicholas MK, George SZ. Psychologically informed interventions for low back pain: an update for physical therapists. Phys Ther 2011;91:765-76.

111 Fullagar $\mathrm{H}$, Skorski S, Duffield R, et al. The effect of an acute sleep hygiene strategy following a late-night soccer match on recovery of players. Chronobiol Int 2016:33:490-505.

112 Tuomilehto $H$, Vuorinen VP, Penttilä E, et al. Sleep of professional athletes: Underexploited potential to improve health and performance. J Sports Sci 2017;35:704-10

113 Lee YC, Chibnik LB, Lu B, et al. The relationship between disease activity, sleep, psychiatric distress and pain sensitivity in rheumatoid arthritis: a cross-sectional study. Arthritis Res Ther 2009;11:R160.

114 Ohayon MM. Pain sensitivity, depression, and sleep deprivation: links with serotoninergic dysfunction. J Psychiatr Res 2009;43:1243-5.
115 Smith MT, Wickwire EM, Grace EG, et al. Sleep disorders and their association with laboratory pain sensitivity in temporomandibular joint disorder. Sleep 2009;32:779-90

116 Kelly GA, Blake C, Power CK, et al. The association between chronic low back pain and sleep: a systematic review. Clin J Pain 2011;27:169-81.

117 Okifuii A, Hare BD. Do sleep disorders contribute to pain sensitivity? Curr Rheumatol Rep 2011;13:528-34

118 Faraut B, Léger D, Medkour T, et al. Napping reverses increased pain sensitivity due to sleep restriction. PLoS One 2015;10:e0117425.

119 Sivertsen B, Lallukka T, Petrie KJ, et al. Sleep and pain sensitivity in adults. Pain 2015;156:1433-9.

120 De Niet GJ, Tiemens BG, Kloos MW, et al. Review of systematic reviews about the efficacy of non-pharmacological interventions to improve sleep quality in insomnia. Int J Evid Based Healthc 2009;7:233-42.

121 Mendoza ME, Capafons A, Gralow JR, et al. Randomized controlled trial of the Valencia model of waking hypnosis plus CBT for pain, fatigue, and sleep management in patients with cancer and cancer survivors. Psychooncology 2016.

122 Winbush NY, Gross CR, Kreitzer MJ. The effects of mindfulness-based stress reduction on sleep disturbance: a systematic review. Explore 2007:3:585-91.

123 Edinger JD, Wohlgemuth WK, Radtke RA, et al. Treatment of chronic primary insomnia: a randomized controlled trial. JAMA 2001;285:1856-64.

124 Vitiello MV, Rybarczyk B, Von Korff M, et al. Cognitive behavioral therapy for insomnia improves sleep and decreases pain in older adults with co-morbid insomnia and osteoarthritis. J Clin Sleep Med 2009:5:355-62.

125 Manber R, Bernert RA, Suh S, et al. CBT for insomnia in patients with high and low depressive symptom severity: adherence and clinical outcomes. J Clin Sleep Med 2011;7:645-52

126 Watkins LR, Hutchinson MR, Milligan ED, et al. "Listening" and "talking" to neurons: implications of immune activation for pain control and increasing the efficacy of opioids. Brain Res Rev 2007;56:148-69.

127 Magni G, Caldieron C, Rigatti-Luchini S, et al. Chronic musculoskeletal pain and depressive symptoms in the general population. An analysis of the 1st National Health and Nutrition Examination Survey data. Pain 1990;43:299-307.

128 Thomas J, Millot JM, Sebille S, et al. Free and total magnesium in lymphocytes of migraine patients - effect of magnesium-rich mineral water intake. Clin Chim Acta 2000;295(1-2):63-75.

129 Trauninger A, Pfund Z, Koszegi T, et al. Oral magnesium load test in patients with migraine. Headache 2002;42:114-9.

130 Geusens P, Wouters C, Nijs J, et al. Long-term effect of omega-3 fatty acid supplementation in active rheumatoid arthritis. A 12-month, double-blind, controlled study. Arthritis Rheum 1994;37:824-9.

131 Gaikwad M, Vanlint S, Mittinity M, et al. Does vitamin D supplementation alleviate chronic nonspecific musculoskeletal pain? A systematic review and meta-analysis. Clin Rheumatol 2017;36:1201-8.

132 Straube S, Derry S, Straube C, et al. Vitamin D for the treatment of chronic painful conditions in adults. Cochrane Database Syst Rev 2015:5:CD007771.

133 Goldberg RJ, Katz J. A meta-analysis of the analgesic effects of omega-3 polyunsaturated fatty acid supplementation for inflammatory joint pain. Pain 2007;129(1-2):210-23.

134 Mauro GL, Martorana U, Cataldo P, et al. Vitamin B12 in low back pain: a randomised, double-blind, placebo-controlled study. Eur Rev Med Pharmacol Sci 2000:4:53-8

135 Brill S, Sedgwick PM, Hamann W, et al. Efficacy of intravenous magnesium in neuropathic pain. Br J Anaesth 2002;89:711-4.

136 Terry R, Posadzki P, Watson LK, et al. The use of ginger (Zingiber officinale) for the treatment of pain: a systematic review of clinical trials. Pain Med 2011;12:1808-18.

137 Agarwal KA, Tripathi CD, Agarwal BB, et al. Efficacy of turmeric (curcumin) in pain and postoperative fatigue after laparoscopic cholecystectomy: a double-blind, randomized placebo-controlled study. Surg Endosc 2011;25:3805-10.

138 Henrotin Y, Priem F, Mobasheri A. Curcumin: a new paradigm and therapeutic opportunity for the treatment of osteoarthritis: curcumin for osteoarthritis management. Springerplus 2013;2:56.

139 Chandran B, Goel A. A randomized, pilot study to assess the efficacy and safety of curcumin in patients with active rheumatoid arthritis. Phytother Res 2012:26:1719-25.

140 Hainline B. Back pain understood. Lenoia, NJ: Medicus Press, 2007

141 Ogilvie-Harris DJ, Gilbart MK, Chorney K. Chronic pain following ankle sprains in athletes: the role of arthroscopic surgery. Arthroscopy 1997;13:564-74.

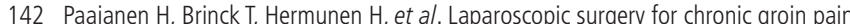
in athletes is more effective than nonoperative treatment: a randomized clinical trial with magnetic resonance imaging of 60 patients with sportsman's hernia (athletic pubalgia). Surgery 2011;150:99-107.

143 Tallon C, Coleman BD, Khan K, et al. Outcome of surgery for chronic achilles tendinopathy. The American Journal of Sports Medicine 2001;29:315-20.

144 Mirza SK, Deyo RA. Systematic review of randomized trials comparing lumbar fusion surgery to nonoperative care for treatment of chronic back pain. Spine 2007;32:816-23. 
145 Ellerton J, Milani M, Blancher M, et al. Managing moderate and severe pain in mountain rescue. High Alt Med Biol 2014;15:8-14.

146 Ellis J. Initial management of acute pain. In: Ramamurthy SAE, Rogers JN, eds. Decision making in Pain Management. 2. Amsterdam: Elsevier, 2006:2-4.

147 McDonagh DZD. The IOC Manual of Emergency Sports Medicine. Hoboken, NJ: Wiley-Blackwell, 2015

148 Lyrtzis C, Natsis K, Papadopoulos C, et al. Efficacy of paracetamol versus diclofenac for Grade II ankle sprains. Foot Ankle Int 2011;32:571-5.

149 Paoloni JA, Orchard JW. The use of therapeutic medications for soft-tissue injuries in sports medicine. Med J Aust 2005;183:384-8.

150 Jones P, Dalziel SR, Lamdin R, et al. Oral non-steroidal anti-inflammatory drugs versus other oral analgesic agents for acute soft tissue injury. Cochrane Database Syst Rev 2015;7:CD007789.

151 Mehallo CJ, Drezner JA, Bytomski JR. Practical management: nonsteroidal antiinflammatory drug (NSAID) use in athletic injuries. Clin I Sport Med 2006;16:170-4.

152 Orchard JW. Benefits and risks of using local anaesthetic for pain relief to allow early return to play in professional football. Br J Sports Med 2002;36:209-13.

153 Raffa RB. Pharmacology of oral combination analgesics: rational therapy for pain J Clin Pharm Ther 2001;26:257-64.

154 Orchard JW, Steet E, Massey A, et al. Long-term safety of using local anesthetic injections in professional rugby league. Am J Sports Med 2010;38:2259-66.

155 Dhillon S. Tramadol/Paracetamol Fixed-Dose Combination. Clinical Drug Investigation 2010:30:711-38

156 Veliz PT, Boyd C, McCabe SE. Playing through pain: sports participation and nonmedical use of opioid medications among adolescents. Am J Public Health 2013;103:e28-e30

157 Feucht CL, Patel DR. Analgesics and anti-inflammatory medications in sports: use and abuse. Pediatr Clin North Am 2010;57:751-74.

158 Moore RA, Wiffen PJ, Derry S, et al. Non-prescription (OTC) oral analgesics for acute pain - an overview of Cochrane reviews. Cochrane Database Syst Rev 2015:CD010794

159 Graham GG, Scott KF, Day RO. Tolerability of paracetamol. Drug Saf 2005:28:227-40.

160 Dahl V, Dybvik T, Steen T, et al. Ibuprofen vs. acetaminophen vs. ibuprofen and acetaminophen after arthroscopically assisted anterior cruciate ligament reconstruction. Eur J Anaesthesiol 2004;21:471-5.

161 Derry CJ, Derry S, Moore RA. Single dose oral ibuprofen plus paracetamol (acetaminophen) for acute postoperative pain. Cochrane Database Syst Rev 2013:CD010210.

162 Juhl G, Norholt S, Tonnesen E, et al. Paracetamol may be started in $2 \mathrm{~g}$ orally, then $1 \mathrm{~g}$ bid 4 for the healthy adult $>60 \mathrm{~kg}$. Eur J Pain 2006;10:371-7.

163 Tokish JM PE, Schlegel T, et al. Ketorolac use in the National Football League: prevalence, efficacy, and adverse effects. Phys Sportsmed The Physician and Sports Medicine 2002;30:19-24.

164 Matava MJ. Ethical Considerations for Analgesic Use in Sports Medicine. Clin Sports Med 2016;35:227-43.

165 Slappendel R, Weber EW, Benraad B, et al. Does ibuprofen increase perioperative blood loss during hip arthroplasty? Eur J Anaesthesiol 2002;19:829-31.

166 Fernández-Serrano MJ, Pérez-García M, Verdejo-García A. What are the specific vs. generalized effects of drugs of abuse on neuropsychological performance? Neurosci Biobehav Rev 2011:35:377-406.

167 Zacny JP. A review of the effects of opioids on psychomotor and cognitive functioning in humans. Exp Clin Psychopharmacol 1995;3:432-66.

168 The World Anti-Doping Code International Standard: prohibited list:WADA, 2017.

169 Coombes BK, Bisset L, Vicenzino B. Efficacy and safety of corticosteroid injections and other injections for management of tendinopathy: a systematic review of randomised controlled trials. Lancet 2010;376:1751-67.

170 Cook JL, Purdam CR. The challenge of managing tendinopathy in competing athletes. Br J Sports Med 2014;48:506-9.

171 Nichols A. Complications associated with the use of corticosteroids in the treatment of athletic injuries. Clinical Journal of Sports Medicine 2005;15:370-5.

172 Cheng J, Abdi S. Complications of joint, tendon, and muscle injections. Tech Reg Anesth Pain Manag 2007;11:141-7.

173 Nepple JJ, Matava MJ. Soft tissue injections in the athlete. Sports Health 2009:1:396-404.

174 Dietzel DP, Hedlund EC. Injections and return to play. Curr Sports Med Rep 2004;3:310-5

175 Engebretsen L, Steffen K, Alsousou J, et al. IOC consensus paper on the use of platelet-rich plasma in sports medicine. Br J Sports Med 2010;44:1072-81.

176 Redler LH, Thompson SA, Hsu SH, et al. Platelet-rich plasma therapy: a systematic literature review and evidence for clinical use. Phys Sportsmed 2011;39:42-51.

177 Smith BJ, Collina SJ. Pain medications in the locker room: To dispense or not. Curr Sports Med Rep 2007:6:366-70.

178 Loveless MS, Fry AL. Pharmacologic therapies in musculoskeletal conditions. Med Clin North Am 2016;100:869-90

179 Jüni P, Hari R, Rutjes AW, et al. Intra-articular corticosteroid for knee osteoarthritis. Cochrane Database Syst Rev 2015:CD005328.
180 McCabe PS, Maricar N, Parkes MJ, et al. The efficacy of intra-articular steroids in hip osteoarthritis: a systematic review. Osteoarthritis Cartilage 2016;24:1509-17.

181 Arroll B, Goodyear-Smith F. Corticosteroid injections for painful shoulder: a metaanalysis. Br J Gen Pract 2005;55:224-8.

182 Gross C, Dhawan A, Harwood D, et al. Glenohumeral Joint Injections. Sports Health 2013;5:153-9.

183 Levine WN, Bergfeld JA, Tessendorf W, et al. Intramuscular corticosteroid injection for hamstring injuries. Am J Sports Med 2000;28:297-300.

184 Gross CE, Hsu AR, Chahal J, et al. Injectable treatments for noninsertional achilles tendinosis: a systematic review. Foot Ankle Int 2013;34:619-28.

185 Krogh TP, Bartels EM, Ellingsen T, et al. Comparative effectiveness of injection therapies in lateral epicondylitis: a systematic review and network meta-analysis of randomized controlled trials. Am J Sports Med 2013:41:1435-46.

186 Pinto RZ, Maher CG, Ferreira ML, et al. Epidural corticosteroid injections in the management of sciatica: a systematic review and meta-analysis. Ann Intern Med 2012;157:865-77.

187 Shamliyan TA, Staal JB, Goldmann D, et al. Epidural steroid injections for radicular lumbosacral pain: a systematic review. Phys Med Rehabil Clin NAm 2014;25:471-89.

188 Kreiner DS, Hwang SW, Easa JE, et al. An evidence-based clinical guideline for the diagnosis and treatment of lumbar disc herniation with radiculopathy. Spine J 2014:14:180-91.

189 Vekaria R, Bhatt R, Ellard DR, et al. Intra-articular facet joint injections for low back pain: a systematic review. Eur Spine J 2016;25:1266-81.

190 Kennedy DJ, Engel A, Kreiner DS, et al. Fluoroscopically guided diagnostic and therapeutic Intra-Articular sacroiliac Joint Injections: a systematic review. Pain Med 2015;16:1500-18.

191 Dragoo JL, Wasterlain AS, Braun HJ, et al. Platelet-rich plasma as a treatment for patellar tendinopathy: a double-blind, randomized controlled trial. Am J Sports Med 2014;42:610-8

192 Fitzpatrick J, Bulsara M, Zheng MH. Effectiveness of Platelet-Rich plasma in the treatment of Tendinopathy: response. Am J Sports Med 2016:44:NP55-6.

193 Krogh TP, Fredberg U, Stengaard-Pedersen K, et al. Treatment of lateral epicondylitis with platelet-rich plasma, glucocorticoid, or saline: a randomized, double-blind, placebo-controlled trial. Am J Sports Med 2013;41:625-35.

194 Lai LP, Stitik TP, Foye PM, et al. Use of platelet-rich plasma in intra-articular knee injections for osteoarthritis: a systematic review. Pm R 2015;7:637-48.

195 Laudy AB, Bakker EW, Rekers M, et al. Efficacy of platelet-rich plasma injections in osteoarthritis of the knee: a systematic review and meta-analysis. Br J Sports Med 2015:49:657-72.

196 Moraes VY, Lenza M, Tamaoki MJ, et al. Platelet-rich therapies for musculoskeletal soft tissue injuries. Cochrane Database Syst Rev 2014:CD010071.

197 Hamid MS, Yusof A, Mohamed Ali MR. Platelet-rich plasma (PRP) for acute muscle injury: a systematic review. PLoS One 2014;9:e90538.

198 Smith PA. Intra-articular autologous conditioned plasma injections provide safe and efficacious treatment for knee osteoarthritis: an FDA-sanctioned, randomized, double-blind, placebo-controlled clinical trial. Am J Sports Med 2016:44:884-91.

199 Jevsevar D, Donnelly P, Brown GA, et al. Viscosupplementation for Osteoarthritis of the Knee. J Bone Joint Surg Am 2015:97:2047-60

200 Hunter DJ. Viscosupplementation for osteoarthritis of the knee. N Eng/ J Med 2015:372:1040-7.

201 Brukner PKK. Clinical Sports Medicine. 5 ed. Australia: McGraw-Hill, 2016

202 Brennan F, Carr DB, Cousins M. Pain management: a fundamental human right. Anesth Analg 2007;105:205-21.

203 Raffa RB. Pharmacology of oral combination analgesics: rational therapy for pain. J Clin Pharm Ther 2001;26:257-64.

204 Tayrose GA, Beutel BG, Cardone DA, et al. The masters athlete: a review of current exercise and treatment recommendations. Sports Health 2015:7:270-6.

205 Aghili RFA, Shiri M. Clinical use of Opioids. Journal of Pharmacoeconomics and Pharmaceutical Management 2015;1:1-5.

206 Dickenson AH. Mechanisms of the analgesic actions of opiates and opioids. Br Med Bull 1991:47:690-702

207 Inturrisi CE. Clinical pharmacology of opioids for pain. Clin J Pain 2002;18:S3-13.

208 McQuay H. Opioids in pain management. The Lancet 1999:353:2229-32.

209 Chou R, Turner JA, Devine EB, et al. The effectiveness and risks of long-term opioid therapy for chronic pain: a systematic review for a National Institutes of Health Pathways to Prevention Workshop. Ann Intern Med 2015;162:276-86.

210 Dowell D, Haegerich TM, Chou R. CDC guideline for prescribing opioids for chronic Pain - United States, 2016. JAMA 2016:315:1624-45.

211 Kato K, Sullivan PF, Evengård B, et al. Chronic widespread pain and its comorbidities: a population-based study. Arch Intern Med 2006;166:1649-54.

212 Le Marec T, Marie-Claire C, Noble F, et al. Chronic and intermittent morphine treatment differently regulates opioid and dopamine systems: a role in locomotor sensitization. Psychopharmacology 2011:216:297-303.

213 Vowles KE, McEntee ML, Julnes PS, et al. Rates of opioid misuse, abuse, and addiction in chronic pain: a systematic review and data synthesis. Pain 2015;156:569-76. 
214 CPSA Standard of Practice: prescribing drugs with potential for Misuse or Diversion. 2017 http://cpsa.ca/standardspractice/prescribing-drugs-misuse-diversion.

215 Franklin GM, Stover BD, Turner JA, et al. Disability Risk Identification Study Cohort. Early opioid prescription and subsequent disability among workers with back injuries: the disability risk identification Study cohort. Spine 2008:33:199-204.

216 Shah A, Hayes CJ, Martin BC. Characteristics of initial prescription episodes and likelihood of Long-Term Opioid Use - United States, 2006-2015. MMWR Morb Mortal Wkly Rep 2017;66:265-9.

217 Feuerstein M. Definitions of pain. Tollison C, Handbook of Chronic Pain Management Baltimore: Williams \& Wilkins, 1989:2-5

218 Scascighini L, Toma V, Dober-Spielmann S, et al. Multidisciplinary treatment for chronic pain: a systematic review of interventions and outcomes. Rheumatology 2008:47:670-8.

219 Flor H, Fydrich T, Turk DC. Efficacy of multidisciplinary pain treatment centers: a meta-analytic review. Pain 1992;49:221-30.

220 Jensen MP, Turner JA, Romano JM. Correlates of improvement in multidisciplinary treatment of chronic pain. J Consult Clin Psychol 1994;62:172-9.

221 Guzmán J, Esmail R, Karjalainen K, et al. Multidisciplinary rehabilitation for chronic low back pain: systematic review. BMJ 2001;322:1511-6.

222 Dworkin $\mathrm{RH}, \mathrm{O}^{\prime}$ Connor AB, Backonja $\mathrm{M}$, et al. Pharmacologic management of neuropathic pain: evidence-based recommendations. Pain 2007;132:237-51

223 Gourlay DL, Heit HA, Almahrezi A. Universal precautions in pain medicine: a rational approach to the treatment of chronic pain. Pain Med 2005;6:107-12.

224 Martell BA, O'Connor PG, Kerns RD, et al. Systematic review: opioid treatment for chronic back pain: prevalence, efficacy, and association with addiction. Ann Intern Med 2007;146:116-27.

225 Turk DC, Dworkin RH, Allen RR, et al. Core outcome domains for chronic pain clinica trials: immpact recommendations. Pain 2003:106:337-45.

226 Ardern CL, Taylor NF, Feller JA, et al. Psychological responses matter in returning to preinjury level of sport after anterior cruciate ligament reconstruction surgery. Am J Sports Med 2013;41:1549-58.

227 Wiffen PJ, Collins S, McQuay HJ, et al. Anticonvulsant drugs for acute and chronic pain. Cochrane Database of Systematic Reviews 2005.

228 Ettinger $A B$, Argoff CE. Use of antiepileptic drugs for nonepileptic conditions: psychiatric disorders and chronic pain. Neurotherapeutics 2007;4:75-83.

229 Micó JA, Ardid D, Berrocoso E, et al. Antidepressants and pain. Trends Pharmacol SCi 2006:27:348-54

230 Blier P, Abbott FV. Putative mechanisms of action of antidepressant drugs in affective and anxiety disorders and pain. J Psychiatry Neurosci 2001;26:37-43.

231 Finnerup NB, Attal N, Haroutounian S, et al. Pharmacotherapy for neuropathic pain in adults: a systematic review and meta-analysis. Lancet Neurol 2015;14:162-73.

232 Sindrup SH, Jensen TS. Efficacy of pharmacological treatments of neuropathic pain: an update and effect related to mechanism of drug action. Pain 1999:83:389-400.

233 Katona I, Freund TF. Endocannabinoid signaling as a synaptic circuit breaker in neurological disease. Nat Med 2008;14:923-30.

234 Lucas P. Cannabis as an adjunct to or substitute for opiates in the treatment of chronic pain. J Psychoactive Drugs 2012:44:125-33.

235 Manchikanti L, Cash KA, Damron KS, et al. Controlled substance abuse and illicit drug use in chronic pain patients: an evaluation of multiple variables. Pain Physician 2006;9:215-25.

236 Narang S, Gibson D, Wasan AD, et al. Efficacy of dronabinol as an adjuvant treatment for chronic pain patients on opioid therapy. J Pain 2008;9:254-64

237 Editorial: football, pain and marijuana. New York Times 2014.

238 Stevens AJ, Higgins MD. A systematic review of the analgesic efficacy of cannabinoid medications in the management of acute pain. Acta Anaesthesio/ Scand 2017:61:268-80.

239 Campbell FA, Tramèr MR, Carroll D, et al. Are cannabinoids an effective and safe treatment option in the management of pain? A qualitative systematic review. BMJ 2001;323:13.

240 Ueda H. Molecular mechanisms of neuropathic pain-phenotypic switch and initiation mechanisms. Pharmacol Ther 2006;109:57-77.

241 Lynch ME, Ware MA. Cannabinoids for the treatment of chronic Non-Cancer pain an updated systematic review of Randomized Controlled Trials. J Neuroimmune Pharmacol 2015;10:293-301.

242 Deshpande A, Mailis-Gagnon A, Zoheiry N, et al. Efficacy and adverse effects of medical marijuana for chronic noncancer pain: systematic review of randomized controlled trials. Can Fam Physician 2015;61:e373-81.

243 Campos DR, Yonamine M, de Moraes Moreau RL. Marijuana as doping in sports. Sports Med 2003;33:395-9.

244 Hansen GR, Streltzer J. The psychology of pain. Emerg Med Clin North Am 2005;23:339-48

245 Orchard J, Best TM, Verrall GM. Return to play following muscle strains. Clin J Sport Med 2005:15:436-41.

246 Heiderscheit BC, Sherry MA, Silder A, et al. Hamstring strain injuries: recommendations for diagnosis, rehabilitation, and injury prevention. J Orthop Sports Phys Ther 2010;40:67-81.
247 Brewer B, Van Raalte JL, Cornelius AE, et al. Psychological factors, rehabilitation adherence, and rehabilitation outcome after anterior cruciate ligament reconstruction. Rehabilitation Psychology 2000;45:20-37.

248 Sutherland AG, Johnston AT, Hutchison JD. The new injury severity score: better prediction of functional recovery after musculoskeletal injury. Value Health 2006;9:24-7.

249 Malliaropoulos N, Isinkaye T, Tsitas K, et al. Reinjury after acute posterior thigh muscle injuries in elite track and field Athletes. Am J Sports Med 2011;39:304-10.

250 Hägglund M, Waldén M, Ekstrand J. Previous injury as a risk factor for injury in elite football: a prospective study over two consecutive seasons. Br J Sports Med 2006;40:767-72

251 Warren P, Gabbe BJ, Schneider-Kolsky M, et al. Clinical predictors of time to return to competition and of recurrence following hamstring strain in elite australian footballers. Br J Sports Med 2010;44:425-9.

252 Ardern CL, Taylor NF, Feller JA, et al. A systematic review of the psychological factors associated with returning to sport following injury. Br J Sports Med 2013:47:1120-6

253 D'Mello R, Dickenson AH, D'Mello RDA. Spinal cord mechanisms of pain. Br J Anaesth 2008;101:8-16.

254 Reid E, Wallwork SB, Harvie D, et al. A New Kind of Spatial Inattention Associated with chronic limb pain? Ann Neurol 2016:79:701-4.

255 Abraira VE, Ginty DD. The sensory neurons of touch. Neuron 2013;79:618-39.

256 Boesch E, Bellan V, Moseley GL, et al. The effect of bodily illusions on clinical pain: a systematic review and meta-analysis. Pain 2016;157:516-29.

257 Wiese-bjornstal DM, Smith AM, Shaffer SM, et al. An integrated model of response to sport injury: Psychological and sociological dynamics. J App/ Sport Psychol 1998;10:46-69.

258 Britton W. Review and critique of models of psychological adjustment to athletic injury. J App/ Sport Psychol 1994;6:87-100.

259 Wiese-Bjornstal DM. Psychology and socioculture affect injury risk, response, and recovery in high-intensity athletes: a consensus statement. Scand J Med Sci Sports;20:103-11.

260 World Anti-Doping Code. Montreal, Canada: Agency WA-D, 2015.

261 Mauger AR, Taylor L, Harding C, et al. Acute acetaminophen (paracetamol) ingestion improves time to exhaustion during exercise in the heat. Exp Physiol 2014:99:164-71.

262 Garcin M, Mille-Hamard L, Billat V, et al. Influence of acetaminophen consumption on perceived exertion at the lactate concentration threshold. Percept Mot Skills 2005; 101:675-83.

263 Foster J, Taylor L, Chrismas BC, et al. The influence of acetaminophen on repeated sprint cycling performance. Eur J App/ Physio/ 2014;114:41-8.

264 Semark A, Noakes TD, St Clair Gibson A, et al. The effect of a prophylactic dose of flurbiprofen on muscle soreness and sprinting performance in trained subjects. J Sports Sci 1999:17:197-203.

265 Tokmakidis SP, Kokkinidis EA, Smilios I, et al. The effects of ibuprofen on delayed muscle soreness and muscular performance after eccentric exercise. J Strength Cond Res 2003;17:53-9.

266 Kraemer WJ, Gómez AL, Ratamess NA, et al. Effects of Vicoprofen and Ibuprofen on Anaerobic Performance after Muscle damage. J Sport Rehabil 2002;11:104-19.

267 Benedetti F, Pollo A, Colloca L. Opioid-mediated placebo responses boost pain endurance and physical performance: is it doping in sport competitions? J Neurosci 2007:27:11934-9.

268 Amann M, Proctor LT, Sebranek JJ, et al. Opioid-mediated muscle afferents inhibit central motor drive and limit peripheral muscle fatigue development in humans. $J$ Physiol 2009;587:271-83.

269 Lorente FO, Peretti-Watel P, Grelot L. Cannabis use to enhance sportive and non-sportive performances among french sport students. Addict Behav 2005:30:1382-91.

270 Steadward RD, Singh M. The effects of smoking marihuana on physical performance. Med Sci Sports 1975:7:309-11.

271 Derman W, Schwellnus M, Jordaan E. Clinical characteristics of 385 illnesses of athletes with impairment reported on the WEB-IISS system during the London 2012 Paralympic Games. Pm R 2014;6:S23-S30.

272 Derman W, Schwellnus MP, Jordaan $\mathrm{E}_{\text {, et }}$ al. The incidence and patterns of illness at the Sochi 2014 Winter Paralympic Games: a prospective cohort study of 6564 athlete days. Br J Sports Med 2016;50:1064-8.

273 Klenck C, Gebke K. Practical management: common medical problems in disabled athletes. Clin J Sport Med 2007;17:55-60.

274 Paolucci S, Martinuzzi A, Scivoletto G, et al. Italian Consensus Conference on Pain in Neurorehabilitation (ICCPN). Assessing and treating pain associated with stroke, multiple sclerosis, cerebral palsy, spinal cord injury and spasticity. Evidence and recommendations from the Italian Consensus Conference on Pain in Neurorehabilitation. Eur J Phys Rehabil Med 2016:52:827-40.

275 Siddall PJ, McClelland JM, Rutkowski SB, et al. A longitudinal study of the prevalence and characteristics of pain in the first 5 years following spinal cord injury. Pain 2003;103:249-57. 
276 Ephraim PL, Wegener ST, MacKenzie EJ, et al. Phantom pain, residual limb pain, and back pain in amputees: results of a national survey. Arch Phys Med Rehabil 2005;86:1910-9.

277 Brunton L, Hall S, Passingham A, et al. The prevalence, location, severity, and daily impact of pain reported by youth and young adults with cerebral palsy. J Pediatr Rehabil Med 2016;9:177-83.

278 Colver A, Rapp M, Eisemann N, et al. Self-reported quality of life of adolescents with cerebral palsy: a cross-sectional and longitudinal analysis. Lancet 2015;385:705-16.

279 Chan SC, Torok-Both GA, Billay DM, et al. Drug analysis at the 1988 Olympic Winter Games in Calgary. Clin Chem 1991;37:1289-96.

280 Aavikko A, Helenius I, Vasankari T, et al. Physician-prescribed medication use by the Finnish Paralympic and Olympic athletes. Clin J Sport Med 2013;23:478-82.

281 Cassell E. The nature of suffering and the goals of Medicine. 2 ed. New York: Oxford University Press, 2004.

282 Messner M. Masculinities and athletic careers. Gender \& Society 1989;3:71-88

283 Sporting Bodies, damaged selves: sociological studies of Sports-Related Injury: emerald Group Publishing Limited, 2004.
284 Hockey J, Allen-Collinson J. Digging in: The sociological phenomenology of 'doing endurance' in distance-running. In: Bridel W, Markula P, Denison J, eds. Endurance running: a Socio-cultural examination. London: routledge, 2016:227-42.

285 Pike E. Doctors just say "rest and take ibuprofen." A critical examination of the role of 'non-orthodox' health care in women's sport. Int Rev Socio/ Sport 2005;40:201-19.

286 Commission IMaS. Olympic Movement Medical Code: international Olympic Committee, 2016.

287 Beauchamp T. Informed Consent plato.stanford.edu2011. 2017 https://plato. stanford.edu/entries/informed-consent.

288 Nixon HL. A social network analysis of Influences on Athletes to play with pain and injuries. Journal of Sport \& Social Issues 1992;16:127-35.

289 Nixon HL. Accepting the risks of pain and injury in sport: mediated cultural influences on playing hurt. Sociol Sport J 1993;10:183-96.

290 Nixon H. Social pressure, social support, and help seeking for pain injuries in college sports networks. Journal of Sport and Social Issues 1994;18:340-55.

291 Shrier I, Safai P, Charland L. Return to play following injury: whose decision should it be. British Journal of Sports Medicine 2013. 


\section{Correction: International Olympic Committee consensus statement on pain management in elite athletes}

Hainline B, Derman W, Vernec A, et al. International Olympic Committee consensus statement on pain management in elite athletes. Br J Sports Med 2017;51:1245-58. 10.1136/ bjsports-2017-097884.

Mark Stuart's affiliation is incorrect. It should be: BPharm FFRPS FRPharmS, BMJ, London, UK.

(c) Article author(s) (or their employer(s) unless otherwise stated in the text of the article) 2018. All rights reserved. No commercial use is permitted unless otherwise expressly granted.

Br J Sports Med 2018;52:206. doi:10.1136/bjsports-2017-097884corr1

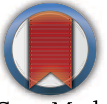

CrossMark 